\title{
A Standard Method for Evaluating Radiocarbon Dates of Local Deglaciation: Application to the Deglaciation History of Southern Labrador and Adjacent Québec La déglaciation du sud du Labrador et des régions avoisinantes du Québec \\ Eine Standard-Methode zur Bewertung von Radiokarbon-Daten zur lokalen Enteisung: Anwendung auf die Enteisungsgeschichte von Süd-Labrador und angrenzendem Québec
}

\author{
George A. King
}

Volume 39, numéro 2, 1985

Tendances climatiques à l'Holocène en Amérique du Nord

URI : https://id.erudit.org/iderudit/032600ar

DOI : https://doi.org/10.7202/032600ar

\section{Aller au sommaire du numéro}

\section{Éditeur(s)}

Les Presses de l'Université de Montréal

\section{ISSN}

0705-7199 (imprimé)

1492-143X (numérique)

\section{Découvrir la revue}

\section{Citer cet article}

King, G. A. (1985). A Standard Method for Evaluating Radiocarbon Dates of Local Deglaciation: Application to the Deglaciation History of Southern Labrador and Adjacent Québec. Géographie physique et Quaternaire, 39(2), 163-182. https://doi.org/10.7202/032600ar

\section{Résumé de l'article}

On a évalué la précision, relativement au moment de la déglaciation, de 62 datations au radiocarbone, effectuées sur des coquillages marins, de sédiments lacustres de base et des dépôts de tourbe de base prélevés dans le sud de la péninsule du Labrador-Ungava. On a ainsi élaboré un mode d'évaluation de la datation des sédiments lacustres qui tient compte des problèmes reliés à la datation des premiers sédiments postglaciaires. Quarante-deux des 62 datations ont servi à établir la chronologie de la déglaciation, à la lumière de la géologie glaciaire de la région. Au Wisconsinien supérieur, les glaciers ont partout progressé jusqu'à la côte, sauf dans l'extrême sud-est du Labrador où la côte était probablement libre de glace. La déglaciation du sud-est du Labrador a commencé vers $13000 \mathrm{BP}$. Lent au début, le retrait glaciaire a ensuite mis en place, entre 9700 et 10500 BP, la moraine Paradise parallèlement à la côte sud-est du Labrador. Par contre, la glace ne s'est pas retirée de la côte aux environs de Sept-îles avant 9400 BP. Peu après, mais sans qu'on puisse en préciser la date, s'est formé le système morainique de la Côte-Nord. On ne connaît pas la situation exacte de la marge glaciaire vers $8000 \mathrm{BP}$. mais elle devait encore se trouver à proximité du système morainique de la Côte-Nord. À partir de ce moment. Ie recul a été rapide; cependant, vers $6500 \mathrm{BP}$, les glaciers occupaient encore de vastes étendues dans l'ouest du Labrador et au Québec tout à côté. Peu après $6000 \mathrm{BP}$. dans deux endroits du centre de la péninsule, la glace a complètement disparu. On a évalué à $\pm 23 \mathrm{~km}$ la précision d'un isochrone glaciaire.
Tous droits réservés @ Les Presses de l'Université de Montréal, 1985
Ce document est protégé par la loi sur le droit d'auteur. L’utilisation des services d'Érudit (y compris la reproduction) est assujettie à sa politique d'utilisation que vous pouvez consulter en ligne.

https://apropos.erudit.org/fr/usagers/politique-dutilisation/ 


\section{A STANDARD METHOD FOR EVALUATING RADIOCARBON DATES OF LOCAL DEGLACIATION: APPLICATION TO THE DEGLACIATION HISTORY OF SOUTHERN LABRADOR AND ADJACENT QUÉBEC*}

George A. KING, Limnological Research Center, 220 Pillsbury Hall, University of Minnesota, Minneapolis, Minnesota 55455, U.S.A.

ABSTRACT Sixty-two radiocarbon dates of marine shells, basal lake sediments, and basal peat deposits from the southeastern part of the Labrador-Ungava Peninsula, Canada, were evaluated for their accuracy and precision in estimating local deglaciation time. A procedure for the consistent evaluation of basal dates of lake sediments was developed after consideration of the problems with dating early-postglacial sediments. Of the 62 dates, 42 were selected to construct the regional deglaciation chronology, interpreted in the context of the glacial geology of the area. Late Wisconsin ice stretched to or beyond the present-day coastline throughout the study area, except in southeastern Labrador where the extreme southeastern coast was probably ice-free during Late Wisconsin time. Deglaciation began in southeastern Labrador by 13.0K. It proceeded slowly at first, and between $9.7 \mathrm{~K}$ and $10.5 \mathrm{~K}$ the retreating ice formed the Paradise Moraine, which parallels the southeastern Labrador coastline. In contrast, the coast at Sept-îles was not icefree until about $9.4 \mathrm{~K}$. Shortly thereafter the extensive Québec North Shore Moraine System developed, although its precise age is uncertain. The position of the ice margin at $8.0 \mathrm{~K}$ is uncertain, but may still have been near the Québec North Shore Moraine System. After $8.0 \mathrm{~K}$ ice retreat was rapid, although extensive ice persisted at $6.5 \mathrm{~K}$ in western Labrador and adjacent Québec. Final wastage of ice occurred in two localities in the center of the Labrador-Ungava Peninsula just after $6.0 \mathrm{~K}$. The precision of the well-dated glacial isochrones is estimated to be about \pm 23 $\mathrm{km}$.
RÉSUMÉ La déglaciation du sud du Labrador et des régions avoisinantes du Québec. On a évalué la précision, relativement au moment de la déglaciation, de 62 datations au radiocarbone, effectuées sur des coquillages marins, de sédiments lacustres de base et des dépôts de tourbe de base prélevés dans le sud de la péninsule du LabradorUngava. On a ainsi élaboré un mode d'évaluation de la datation des sédiments lacustres qui tient compte des problèmes reliés à la datation des premiers sédiments postglaciaires. Quarante-deux des 62 datations ont servi à établir la chronologie de la déglaciation, à la lumière de la géologie glaciaire de la région. Au Wisconsinien supérieur, les glaciers ont partout progressé jusqu'à la côte, sauf dans l'extrême sud-est du Labrador où la côte était probablement libre de glace. La déglaciation du sud-est du Labrador a commencé vers $13000 \mathrm{BP}$. Lent au début, le retrait glaciaire a ensuite mis en place, entre 9700 et 10500 BP, la moraine Paradise parallèlement à la côte sud-est du Labrador. Par contre, la glace ne s'est pas retirée de la côte aux environs de Sept-îles avant 9400 BP. Peu après, mais sans qu'on puisse en préciser la date, s'est formé le système morainique de la Côte-Nord. On ne connaît pas la situation exacte de la marge glaciaire vers $8000 \mathrm{BP}$. mais elle devait encore se trouver à proximité du système morainique de la Côte-Nord. A partir de ce moment, le recul a été rapide; cependant, vers $6500 \mathrm{BP}$, les glaciers occupaient encore de vastes étendues dans l'ouest du Labrador et au Québec tout à côté. Peu après $6000 \mathrm{BP}$, dans deux endroits du centre de la péninsule, la glace a complètement disparu. On a évalué à $\pm 23 \mathrm{~km}$ la précision d'un isochrone glaciaire.
ZUSAMMENFASSUNG Eine StandardMethode zur Bewertung von RadiokarbonDaten zur lokalen Enteisung: Anwendung auf die Enteisungsgeschichte von Süd-Labrador und angrenzendem Québec. 62 Radiokarbon-Daten von marinen Muscheln, Seebodensedimenten und Boden-Torf-Ablagerungen aus dem südöstlichen Teil der Labrador-Ungava-Halbinsel, Kanada, wurden bezüglich ihrer Genauigkeit und Präzision bei der Berechnung der lokalen Enteisungs-Zeit bewertet. Eine Methode zur folgerichtigen Bewertung der Boden-Daten von See-Sedimenten wurde unter Berücksichtigung der Probleme bei der Datierung früher postglazialer Sedimente entwickelt. Von den 62 Daten wurden 42 ausgewählt, um die regionale Enteisungs-Chronologie zu rekonstruieren, integriert in den Kontext der glazialen Geologie des Gebiets. Das späte Wisconsin-Eis reichte bis zur heutigen Küstenlinie oder sogar über sie hinaus im ganzen studierten Gebiet, außer im südöstlichen Labrador, wo die äußerste südöstliche Küste im späten Wisconsin wahrscheinlich eisfrei war. Die Enteisung begann in Süd-Ost-Labrador um 13.OK. Sie schritt zuerst langsam weiter vor und zwischen 9.7K und $10.5 \mathrm{~K}$ bildete das zurückweichende Eis die Paradise-Moräne, welche parallel zur Süd-Ost-Küste Labrador liegt. Im Gegensatz dazu war die Küste von Sept-îles nicht eisfrei bis ungefähr $9.4 \mathrm{~K}$. Kurz danach entwickelte sich des ausgedehnte Nord-Küste-MoränenSystem Québecs, wenn auch sein genaues Alter ungewi $\beta$ ist. Die Position der Eis-Grenze um 8.OK ist nicht sicher, kann aber immer noch in der Nähe des Nord-Kuste-MoränenSystems von Québec gewesen sein. Nach 8.OK war der Rückgang schnell, obgleich es ausgedehntes Eis um 6.5K in West-Labrador und im angrenzenden Québec gab. Der endgültige Schwund des Eises fand in zwei Ölichkeiten im Zentrum der Labrador-Ungava-Halbinsel direkt nach 6.OK statt. Man schätzt, da $\beta$ die Genauigkeit der gut datierten glazialen Isochrone ungefähr $\pm 23 \mathrm{~km}$ beträgt.

\footnotetext{
* Contribution No. 314, Limnological Research Center, University of Minnesota
} 


\section{INTRODUCTION}

Final wastage of the Laurentide Ice Sheet occurred after 6.0K in the center of the Labrador-Ungava Peninsula (IVES, 1960a; HUGHES, 1964; RICHARD et al., 1982). The timing and pattern of the preceding ice retreat on the peninsula were poorly known until recently because few dates indicating local deglaciation time were available from the interior. Several deglaciation chronologies for the region have been published (PREST, 1969; BRYSON et al., 1969; IVES et al. 1975; HILLAIRE-MARCEL and OCCHIETTI, 1980; MAYEWSKI et al., 1981), but these reconstructions are imprecise because of the lack of data from the interior.

The number of radiocarbon dates from basal lake sediments in Labrador and adjacent Québec has recently increased dramatically through the work of RICHARD et al. (1982), LAMB (1985), ENGSTROM and HANSEN (1985), and KING (1986). The giacial geology of the region is also better known now through the work of DREDGE (1976a,b, 1983), DUBOIS (1977, 1979), FULTON and HODGSON (1979), and DUBOIS and DIONNE (1985). This abundance of new information, together with that previously published, is used to construct a revised deglaciation chronology for the southeastern part of the Labrador-Ungava Peninsula.

The dates used in the reconstruction are from three types of materials: marine shells from early-postglacial deposits, basal lake sediments, and basal peat deposits. Before the chronology was constructed each date was evaluated to determine how well it represents the local deglaciation time. Two flow charts, one for marine shell dates and one for limnic sediments, outline the steps followed in the evaluation of each date. Also, in the case of lake sediments, several methods were used to estimate the number of years between the beginning of deglaciation in an area and the time when the dated sediment was deposited. A list of all the dates compiled from the region, relevant data about each date, their evaluation, and adjustments made to them (if any), are given in the appendix for easy reference.

\section{STUDY AREA}

The deglaciation chronology was drawn for the southeastern part of the Labrador-Ungava peninsula, specifically the area north of the Gulf of St. Lawrence, west of the Labrador Sea, south of $56^{\circ} \mathrm{N}$, and east of $71^{\circ} \mathrm{W}$ (Fig. 1). This region includes the areas of final wastage of Laurentide ice and the locations of most of the new basal dates from the peninsula.

\section{PHYSIOGRAPHY AND GEOLOGY}

The study area consists of ten major physiographic regions (Fig. 2, HARE, 1959). The highlands in the southwestern quarter of the study area form part of the Laurentide Massif, which stretches $130 \mathrm{~km}$ north from the Gulf of St. Lawrence at Sept-iles and east to about $63^{\circ} \mathrm{W}$. Elevations in the massif average $800-900 \mathrm{~m}$, but a narrow lowland separates the highlands from the Gulf. The major rivers in the massif flow southward to the Gulf, and some flow through deep gorges.

East and northeast of the massif, in southeastern Labrador and adjacent Québec, is the Southeastern Plateau Belt. Bed- rock controls the local topography here and relief is low. Elevations average 400-500 m.

North of the Southeastern Plateau Belt is the Mealy Mountain Massif, a small but prominent plateau-topped upland. Most of the upland is higher than $600 \mathrm{~m}$, with the highest points just over $1000 \mathrm{~m}$. Its northern edge drops abruptly to the Lake Melville depression that stretches $200 \mathrm{~km}$ inland from the Atlantic coast.

The central part of the study area is occupied by the relatively small Moraine-Mecatina, Hamilton-Naskaupi, and Double Mer drift belts and the large drift-covered Lake Plateau. Relief is also low in these areas, and elevations average 500-650 m. At the eastern edge of the Lake Plateau is the Red WineRomaine-Fleur-de-Mai axis, consisting of three minor massifs. Only 150-300 m separates the highest hills in these areas and the general level of the Lake Plateau.

Northeast of the Lake Plateau and extending to the coast is the Eastern Plateau Belt. Glacial drift is virtually absent from this area and elevations average $200-500 \mathrm{~m}$.

In the northwestern part of the study area the Caniapiscau Massif forms a rugged upland with elevations averaging 550$600 \mathrm{~m}$. In contrast, the Western Plateau Belt has subdued relief and extensive glacial features. East of these two areas, in the north-central portion of the study area, is the Labrador Trough. Its ridge-and-valley relief give it a distinctive physiography. The sub-parallel ridges trend north-northwest. The pattern is the result of differential erosion of the folded sedimentary bedrock underlying the Trough, which consists of sandstones, dolomites, cherts, and iron formation (GREENE, 1974).

The rest of the study area is underlain by Precambrian intrusive and high grade metamorphic rock (GREENE, 1974).

\section{METHODS}

Three types of geologic materials are commonly dated to give estimates of local deglaciation time: marine shells deposited at times of maximum postglacial sea-level, basal limnicsediments on top of glacial deposits, and basal peat. The literature was reviewed to compile all the published dates of these materials in the study area, and new dates were obtained from the basal sediments of 16 lakes cored in western Labrador and adjacent Québec in July of 1981 and 1982 (KING, 1986). The basal sediments were sampled by either multiple drives with a $5 \mathrm{~cm}$ piston corer (WRIGHT et al., 1984) or a single drive with a $7.5 \mathrm{~cm}$ piston corer in order to minimize the thickness of the dated sample. The amount of organic matter in the basal sediments was estimated by loss on ignition of the basal sediments at $550^{\circ} \mathrm{C}$ (DEAN, 1974). Only samples with an average organic matter content of $4 \%$ or greater were submitted for dating, in order to limit the effects of possible contamination of the sample by older carbon (BJÖRCK and HAKANSSON, 1982). Also, all samples submitted for dating contained at least four grams of organic matter to ensure that sufficient carbon was present for dating. Samples were wrapped in plastic and aluminum foil and submitted to the radiocarbon laboratory of the Geological Survey of Canada for dating. 


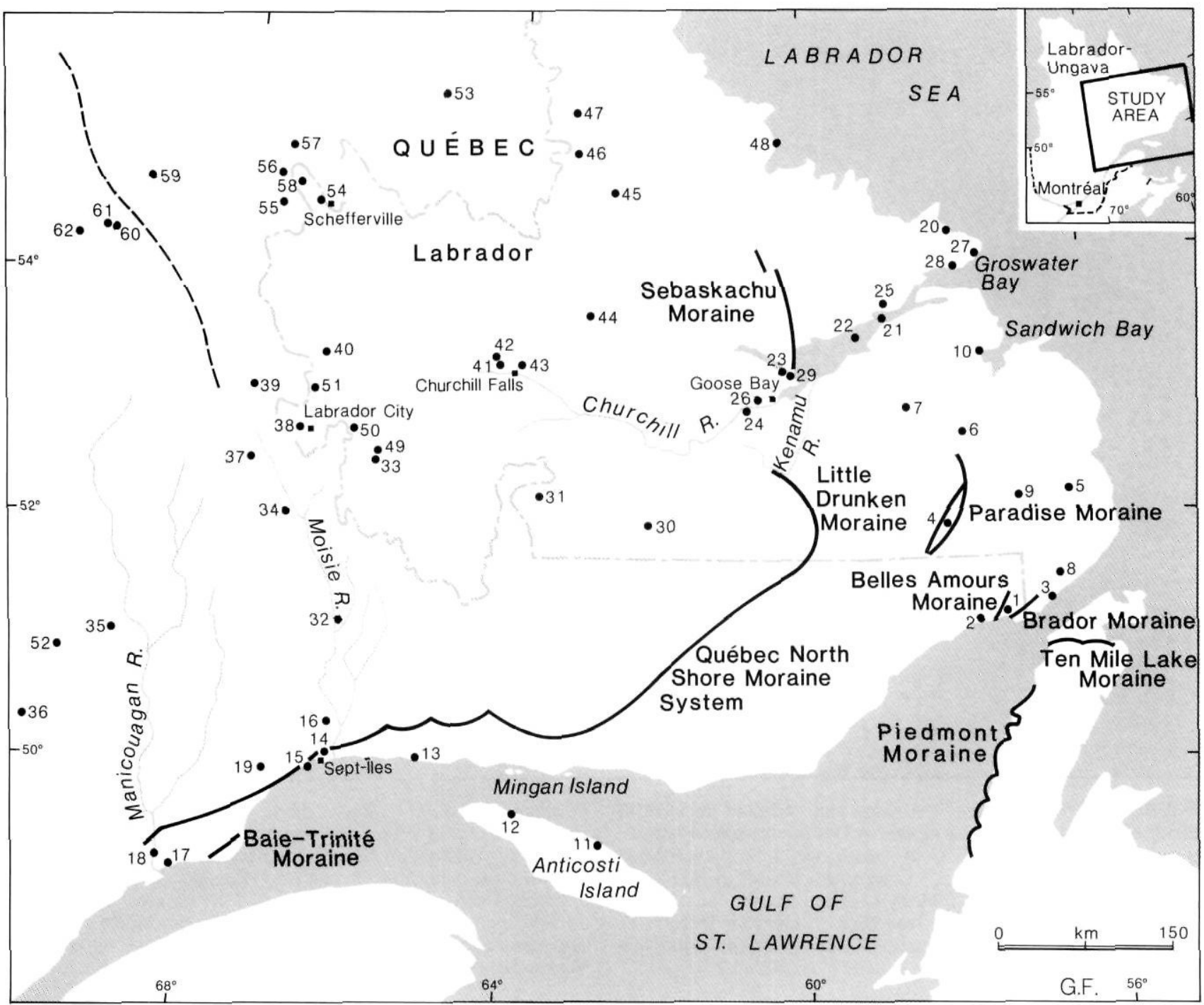

FIGURE 1. Map of the study area, showing the location of the carbon dates listed in the appendix. Numbers next to a dot identify the sites in the appendix and the text. Major end-moraines are indicated by heavy solid lines, while the ice-divide of HUGHES (1964) is indicated by a dashed-line.

\section{EVALUATION OF RADIOCARBON DATES}

After the data set was assembled, the dates were evaluated as to how well they estimate local deglaciation time by considering the many factors that influence their accuracy and precision. Steps in the evaluation of the dates are summarized in flow charts (Figs. 3 and 4 ) and are discussed in detail below. At the end of each branch in the flow charts, which indicate that a decision on the accuracy of a particular date has been reached, a letter is printed that is used in the data table to indicate how a date was evaluated. These symbols and their definitions are summarized in Table $\mathrm{l}$.

A first consideration for all three types of dated material was that the radiocarbon age of a sample is not the true calendar age of the sample even assuming no contamination
Carte de sites où ont été effectuées les datations au radiocarbone. Les chiffres correspondent à ceux du texte et de la liste donnée en appendice. Les lignes grasses représentent les moraines frontales les plus importantes; les tiretés, la ligne de partage des glaces, selon HUGHES (1964).

by ${ }^{14} \mathrm{C}$ older or younger than that present when the sample was deposited. Comparison of dendrological and radiocarbon dates of tree cores has shown that atmospheric ${ }^{14} \mathrm{C}$ has changed with time (DAMON et al., 1970; SUESS, 1970). For example, the radiocarbon date of a sample younger than $2.0 \mathrm{~K}$ will be younger than the sample's true sidereal age. However, in this study corrections for varying ${ }^{14} \mathrm{C}$ were not made, and all reported ages are in radiocarbon years.

\section{Marine Shell Dates}

Marine shell dates were evaluated with two criteria. First, the stratigraphic position of a dated shell must indicate that it was deposited immediately after the local area was deglaciated (Step 1a, Fig. 3). For example, dates of shells deposited in littoral sediments near maximum sea level should give good 


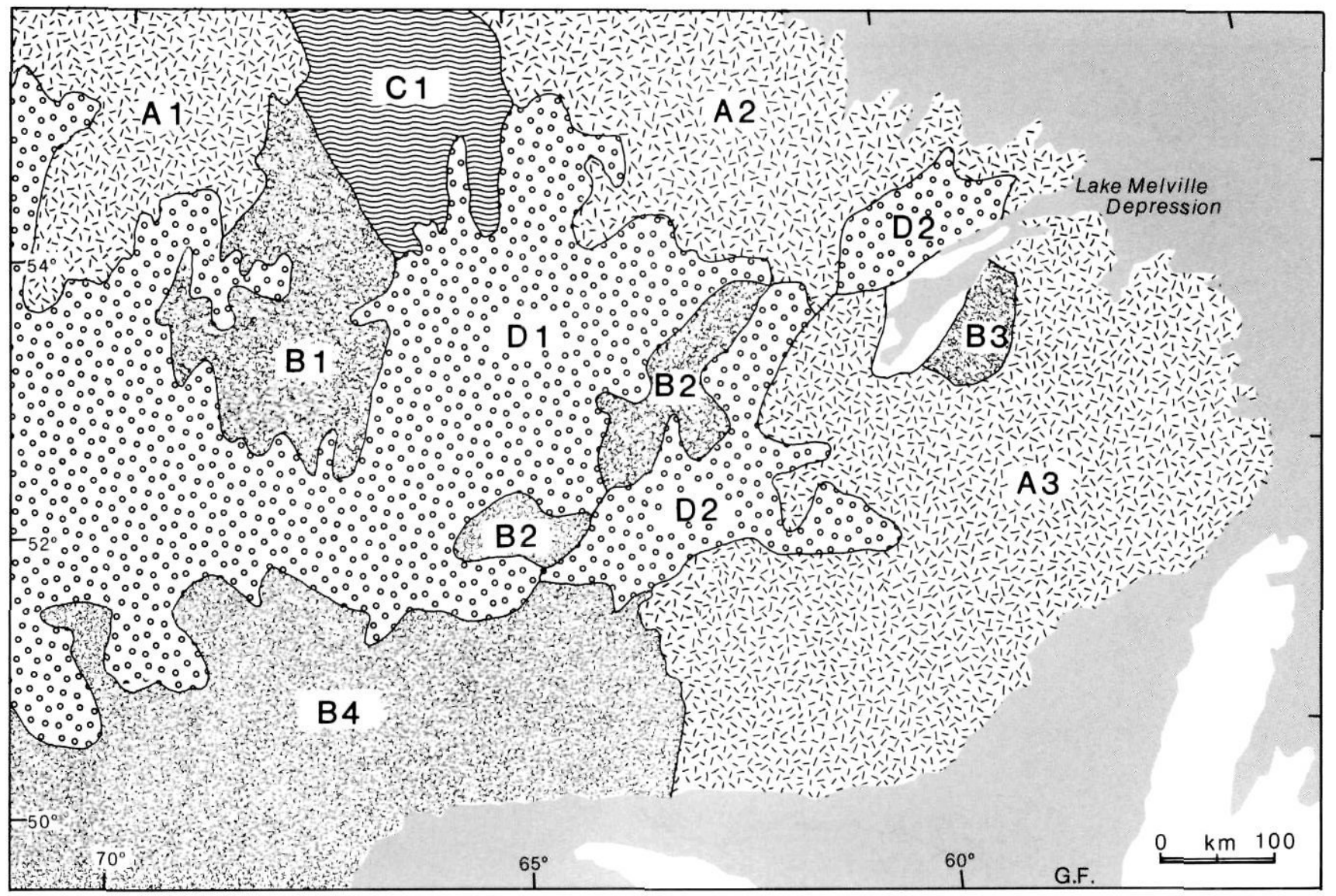

FIGURE 2. Physiography of the study area, adapted from HARE (1959). Key to the physiographic regions: A. Bedrock-controlled Plateaus: 1) Western Plateau Belt; 2) Eastern Plateau Belt; 3) Southern Plateau Belt. B. Upland Areas-Massif: 1) Caniapiscau Massif; 2) Red-WineRomaine-Fleur de Mai axis; 3) Mealy Mountain Massif; 4) Laurentide Massif. C. Upland Areas-Appalachian Type: 1) Labrador Through. D. Drift-covered Belt: 1) Lake Plateau; 2) Moraine-Mecatina, HamiltonNaskaupie, Double Mer Belts.
Physiographie de la région à l'étude, adapté de HARE (1959). A. Plateau de roches cristallines: 1) plateaux de l'Ouest; 2) plateaux del'Est; 3) plateaux du Sud-Est. B. Massifs des hautes terres: 1) plateau du Caniapiscau; 2, axe Red-Wine-Romaine-Fleur de Mai; 3) monts Mealy; 4) plateau laurentidien. C. Hautes terres de type appalachien: 1) fosse du Labrador. D. Zône de dépôts glaciaires: 1) plateau des lacs; 2) zones de Moraine-Mecatina, de HamiltonNaskaupie, de Double Mer.

\begin{tabular}{|c|c|c|}
\hline $\begin{array}{l}\text { 1a. Is the stratigraphic position } \\
\text { of the dated shells indicative } \\
\text { of the deglaciation time in } \\
\text { the area? }\end{array}$ & $-\mathrm{No} \longrightarrow$ & $\begin{array}{l}\text { Date not } \\
\text { used. N1 }\end{array}$ \\
\hline $\begin{array}{c}\text { Yes } \\
\downarrow\end{array}$ & & \\
\hline $\begin{array}{l}\text { 2a. Is the date consistent with } \\
\text { the other dates in the region? }\end{array}$ & - No $\longrightarrow$ & $\begin{array}{l}\text { Recheck la for this date } \\
\text { and other dates from the } \\
\text { area. If the la response } \\
\text { is still yes, the date is not } \\
\text { used in the reconstruction. } \\
\text { If date is too old, N5; if } \\
\text { date is too young, N6. }\end{array}$ \\
\hline
\end{tabular}

3a. Date used in reconstruction, $G$ Normalization of dates to $13 \mathrm{C}=0 \%$. PDB considered when comparing these dates with dates from terrestrial qazterial that are normalized to $13 \mathrm{C}=-25 \%$.PDB.
FIGURE 3. Flow chart for the evaluation of marine dates. Evaluation de la date des coquillages marins. 


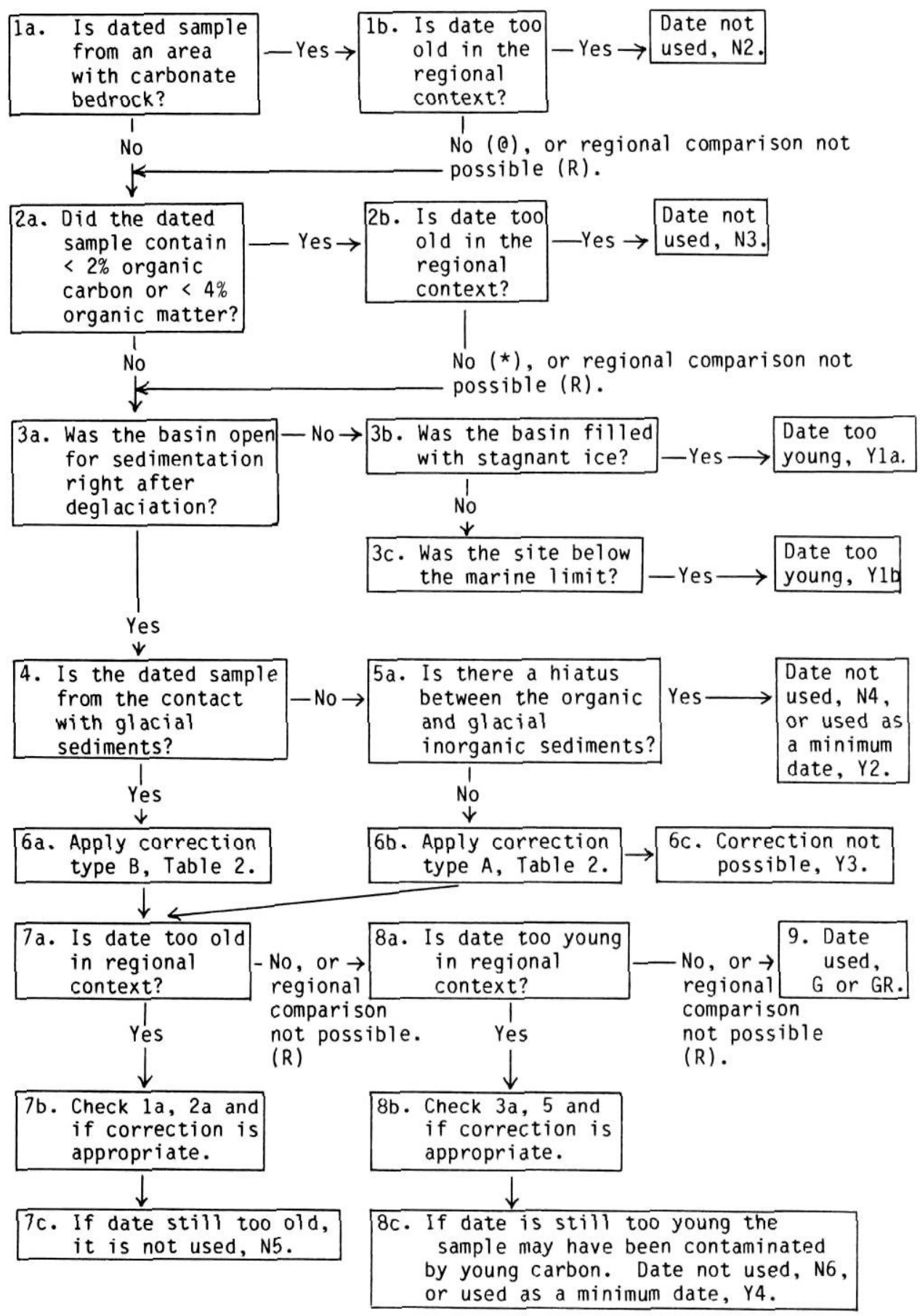

FIGURE 4. Flow chart for the evaluation of basal dates of limnic sediments.

Évaluation de la date des sédiments lacustres de base

estimates of the timing of local deglaciation. Second, if other shell dates have been obtained from a region, each date was evaluated in a regional context (Step 1b, Fig. 3). If a date is significantly younger or older than the other dates in the region, it is not used in the reconstruction.

Shell dates meeting these two requirements are used in the reconstruction, although two additional factors complicate their interpretation. First, marine shell dates are commonly normalized to a $\delta{ }^{13} \mathrm{C}=0 \%$, PDB, while dates of terrestrial material are normalized to $\delta{ }^{13} \mathrm{C}=-25 \%$. PDB, the average value for terrestrial plants (MANGERUD and GULLIKSEN, 1975). Thus shell and terrestrial dates are not strictly comparable. To make them so, shell dates should be normalized to $\delta{ }^{13} \mathrm{C}=-25 \%$. PDB by adding 412 years to each date (MANGERUD, 1972).

Second, ${ }^{14} \mathrm{C}$ in ocean water is at a disequilibrium with atmospheric ${ }^{14} \mathrm{C}$ due to the slow-mising of surface waters and deep water masses. This disequilibrium results in ocean surface waters between $40^{\circ} \mathrm{N}$ and $40^{\circ} \mathrm{S}$ having an apparent age of 320-520 years, and waters farther north an age up to 
TABLE I

Key for symbols used in Figures 2 and 3, and Appendix

\begin{tabular}{|c|c|}
\hline Symbol & Definition \\
\hline C & Calculated correction is uncertain \\
\hline G & Date represents local deglaciation time. \\
\hline N1 & $\begin{array}{l}\text { Stratigraphic position of shell indicates it wasn't deposited } \\
\text { during the local deglaciation. }\end{array}$ \\
\hline N2 & $\begin{array}{l}\text { Date is too old probably because of contamination by } \\
\text { older carbon from carbonate bedrock. }\end{array}$ \\
\hline (a) & $\begin{array}{l}\text { Dated sample from area with carbonate bedrock but is } \\
\text { not too old in the regional context. }\end{array}$ \\
\hline N3 & $\begin{array}{l}\text { Date is too old probably because of the relatively great } \\
\text { influence of older carbon on the }{ }^{14} \mathrm{C} \text { activity of the sample. }\end{array}$ \\
\hline * & $\begin{array}{l}\text { Dated sample has }<2 \% \text { organic carbon or }<4 \% \text { organic } \\
\text { matter, but date is not too old in the regional context. }\end{array}$ \\
\hline N4 & $\begin{array}{l}\text { A hiatus is present between the dated sample and glacial } \\
\text { sediments. (See Y2). }\end{array}$ \\
\hline N5 & $\begin{array}{l}\text { Date is too old in the regional context, probable reason } \\
\text { unknown. }\end{array}$ \\
\hline N6 & $\begin{array}{l}\text { Date is too young in the regional context; contamination } \\
\text { by younger carbon is a possibility (see Y4). }\end{array}$ \\
\hline $\mathrm{O}$ & Not enough information available to evaluate date. \\
\hline $\mathrm{R}$ & Regional comparison unable to be made. \\
\hline Y1a & $\begin{array}{l}\text { Basin not open for sedimentation during deglaciation } \\
\text { as it was probably filled with stagnant ice for hundreds } \\
\text { of years after deglaciation. }\end{array}$ \\
\hline $\mathrm{Y} 1 \mathrm{~b}$ & $\begin{array}{l}\text { Basin not open for sedimentation during deglaciation } \\
\text { because the site was below the marine limit. }\end{array}$ \\
\hline Y2 & $\begin{array}{l}\text { A hiatus occurs between the dated sample and glacial } \\
\text { sediments, so the reported date gives only a minimum } \\
\text { date for deglaciation in the region. This is usually the } \\
\text { case for basal peat dates. }\end{array}$ \\
\hline Y3 & $\begin{array}{l}\text { Correction for height of the sample above the glacial } \\
\text { sediments not possible. Date is a minimum deglaciation } \\
\text { time. }\end{array}$ \\
\hline Y4 & $\begin{array}{l}\text { Date is too young in the regional context, but still used } \\
\text { in the deglaciation chronology as a minimum date of } \\
\text { local deglaciation. }\end{array}$ \\
\hline
\end{tabular}

$800-900$ years (dates normalized to $\delta{ }^{13} \mathrm{C}=-25 \%$ 。 PDB)(BROECKER et al., 1960). The apparent age of ocean water has affected the radiocarbon age of shells deposited within the last century, as shells deposited along the Norway coast have an average apparent age of 440 years, while those from Ellesmere Island, Canada, average 750 years (dates normalized to $\delta{ }^{13} \mathrm{C}=-25 \%$ ) (MANGERUD and GULLIKSEN, 1975). Thus, dates of fossil shells are likely to be a few hundred years older than terrestrial materials the same age as the shells.

These two biases in marine shell dating are thus opposite in their effect. The bias towards younger dates because of differing corrections for isotopic fractionation can be eliminated, but in the study area the bias towards older dates caused by the disequilibrium between atmospheric and oceanic ${ }^{14} \mathrm{C}$ can not be corrected, as the apparent age of modern shells in the area is unknown. In this study these two biases are assumed to be equal and thus cancel each other out. Therefore, no corrections for either of these biases are made in the table summarizing the dates from the region (Appendix). Evidence in support of this assumption is provided by the almost identical ages of a marine shell $(6700 \pm 170, \mathrm{QU}-210)$ and wood fragment (6750 $\pm 240, \mathrm{QU}-211)$ at the same stratigraphic position in an area near Sept-Îles (DIONNE, 1977). Nevertheless, this assumption should be tested and caution must be used in comparing dates from these two different materials.

\section{Lake-Sediment Dates}

The evaluation of the dates of basal limnic sediments involved the consideration of two major issues: (1) whether the reported age of a sample is the sample's true radiocarbon age, and, (2), whether the dated sediment was deposited during deglaciation or sometime later. These two issues are considered separately below. Methods used to evaluate each date are presented in the context of the discussion of the specific problems of dating basal limnic sediments and are summarized in a flow chart (Fig. 4).

Two processes can alter the ${ }^{14} \mathrm{C}$ content of a sample so that its reported age is different from its actual radiocarbon age. First, the sample can be contaminated by old carbon during its deposition, resulting in a reported age older, sometimes significantly older, than the sample's true radiocarbon age. In newly deglaciated landscapes contamination of sediments is a particularly serious problem, as old carbon can be released from rocks through glacial scouring and washed into newly formed lakes by glacial meltwater (SUTHERLAND, 1980). Carbonate bedrock in particular contains significant amounts of carbon, although even granites and metamorphosed sedimentary rocks may contain some carbon. Old carbon can reach lake bottoms directly by sedimentation of mineral particles containing inorganic carbon, or indirectly by dissolution into lake water and subsequent uptake by algae which later die and are incorporated into the lake's sediment, i.e. the "hard-water effect" (DEEVEY et al., 1954).

An additional source of old carbon during deglaciation is glacial meltwater containing old carbon dioxide that was entrapped in glacial ice (SUTHERLAND, 1980). Although old carbon dioxide would rapidly equilibrate with atmospheric carbon dioxide as a meltwater stream flowed away from the ice margin, a lake near the ice margin might receive old carbon in the meltwater for several decades to perhaps a hundred years, depending on the rate of ice-retreat. Algal uptake of the old carbon and their subsequent sedimentation would bias the radiocarbon age of the early- postglacial sediments (SUTHERLAND, 1980).

Contamination of sediments with old carbon is most serious when the organic content of a sample is low, for a relatively small amount of old carbon can account for a significant fraction of the total amount of carbon in the sample (SUTHERLAND, 1980; BJÖRCK and HAKANSSON, 1982). A radiocarbon date of such a sample will thus differ greatly from the sample's actual radiocarbon age. Generally samples with $<2 \%$ organic carbon (dry weight) or $<4 \%$ organic matter have a relatively high probability of giving unreliable dates (FILLON et al., 1981; BJÖRCK and HAKANSSON, 1982).

The following procedure was used to evaluate the basal dates of limnic sediments in regard to the problems of contamination by older carbon. Dates from areas with carbonate bedrock are not used in the reconstruction if they are signi- 
ficantly older than other dates from nearby areas without carbonate bedrock (Step 1a, Fig. 4). The same applies to samples with less than $2 \%$ organic carbon or $4 \%$ organic matter (Step 2b, Fig. 4). If other dates in the region are not available for comparison the suspect date was considered as potentially unreliable and marked by an R (Table I). However, it is used in the reconstruction.

Another way the ${ }^{14} \mathrm{C}$ content of a sample can be altered is by contamination with younger carbon from bacterial or fungal growth on the sample before it is dated (GEYH et al. 1974; J. KING et al., 1983). The probability of such contamination occurring increases with time since sampling. Curves showing the error in age determinations with varying amounts of contamination by young carbon are given in GROOTES (1983). For example, 5\% contamination of a 10,000 yr old sample will give a relative age error of $-10 \%$. The older the sample, the greater the error. Examples of suspected contamination of actual samples are given in J. KING et al. (1983).

The only indication of contamination of a dated sample, other than observing fungal growth on the sample, comes from comparison of the date with other reliable dates in the region. If the date is too young, perhaps it has been contaminated by younger carbon. However, there are many other reasons that a date may be too young in a regional context (discussed below), and in this study these were evaluated before a decision on contamination was reached (Step $8 \mathrm{c}$, Fig. 4).

Even if a radiocarbon date represents the actual radiocarbon age of a sample, how accurately it represents the deglaciation time in an area depends on the history of sedimentation in the lake basin and the relative position of the dated sample in the stratigraphic sequence. Thus, the following factors were also examinated in the evaluation of each basal date not yet eliminated from consideration for use in the deglaciation reconstruction.

The initial consideration was that the basin from which the dated sediment was obtained must have become ice-free early during local deglaciation (Step 3b, Fig. 4). It is not uncommon for stagnant ice covered by drift to persist in a lake basin for several hundred or thousand years after deglaciation (FLORIN and WRIGHT, 1969; DRISCOLL, 1980). Not until the ice melts do sediments begin accumulating in these basins, and dates of the basal sediments in such basins may be much younger than the actual age of deglaciation. Clues used to establish whether stagnant ice likely persisted in a basin or not are (1), the presence of basal organic debris on top of the glacial sediments and (2), a strongly developed stagnantice topography surrounding the basin (FLORIN and WRIGHT, 1969; Step 3b, Fig. 4). Dates from basins with these features are not used in the reconstruction.

Lake basins below the maximum marine limit in an area will also not have early postglacial sediments, and dates of the basal sediments of these lakes will not represent the local deglaciation time (Step 3c, Fig. 4). Therefore these dates are not used in the reconstruction.

Even if a basin was open during the final stages of deglaciation the basal sediments may be glacially derived and largely inorganic, and unlikely to be accurately dated because of their low carbon content. Thus basal samples submitted for dating are usually taken from sediments where the organic component begins to increase. Such samples really date the beginning of organic deposition at the core site rather than the local deglaciation time (RICHARD et al., 1982). The stratigraphy of each core dated was reviewed to determine if the dated section is at the contact of organic sediments with glacial-lacustrine sediments or above it (Step 4, Fig. 4). If it is above the contact the following two factors were considered to determine if there was an inordinate length of time between deglaciation and the start of organic deposition at a core site.

First, whereas glacial sediments tend to be distributed evenly over the lake basin, organic sediments tend to be focused into the deeper parts of the basin (DAVIS and FORD, 1982). Thus if a core is taken from a shallow part of the lake there may be a hiatus between the glacial sediments and the first organic sediments deposited at the site, yielding a date younger than the date of deglaciation. Abrupt changes in pollen stratigraphy or sediment lithology can indicate such a hiatus in a core (Step 5a, Fig. 4), and dates from such cores are not used in the reconstruction.

A second factor influencing the beginning of organic sedimentation is the climate after deglaciation. If the climate was cold, productivity in the lake and watershed would have been low, resulting in little organic sedimentation. Thus dates of the organic sediments from those lakes will be younger than the deglaciation age (HYVÄRINEN, 1973). In the study area, the regional climate was cold until at least 8.0K (KING, 1986), so dates older than $8.0 \mathrm{~K}$ may not reflect the local deglaciation time as well as those younger than $8.0 \mathrm{~K}$.

For all limnic dates, regardless of stratigraphic position, the thickness of the dated sample will also affect the relationship of a basal date and the deglaciation time. Since a vertical section of lake sediment represents a non-linear gradient in ${ }^{14} \mathrm{C}$ activity because of the exponential decay of ${ }^{14} \mathrm{C}$, a date of a section of lake sediment is weighted toward the younger end of the sample and is younger than the arithematic average of the age of the sediment. The greater the thickness of the dated sample, the greater becomes the difference between the deglaciation time and the reported age (SUTHERLAND, 1980). Thus, the thickness of each dated sample is included in the Appendix. Part of the bias is eliminated by estimating the number of years represented by the sediment deposited between the midpoint and base of a dated sample, as discussed below.

\section{Methods for Revising Basal Dates of Lake Sediments}

Even if the problems of dating basal lake sediments are controlled as much as possible, i.e. (1) if the site chosen is appropriate for sampling, (2) if care is taken to ensure that the sample is not too thick, and (3) if enough carbon is present in the sample to reduce the effect of contamination by older carbon, these constraints on sample choice mean that most of the dates not eliminated from the data set after the evaluating steps 1-5 (Fig. 4) are still somewhat younger than the age of deglaciation. These dates were revised by one of several 
methods in order ot give the best estimate of the deglaciation time at a particular site (Table II).

If a sample submitted for dating is above the contact of organic and glacial sediments (Step 6b, Fig. 4), two techniques were used to estimate the deglaciation time (Part A, Table II). First, if pollen data from the core is available and the regional vegetation as inferred from the pollen data was the same while the undated sediment above the contact with glacial sediments was being deposited, the pollen influx to the core site was assumed to be constant during that interval. Then the average pollen concentration of the sediment between the midpoint of the dated sample and the contact with glacial sediments was calculated and divided by the pollen influx at the dated level in order to estimate the deposition time in the undated interval. Multiplying that number by the length of the undated segment and adding it to the basal date gives an estimate of the age of the giacial contact (Method A1, Table II; RICHARD et al., 1982). An example of this calculation is given in Table III.

\section{TABLE II}

Methods for correcting radiocarbon dates of basal lake sediments

A. If dated sample is above the contact with glacial sediments, and ...

1. If the following criteria are met:

a) pollen data are available;

b) vegetation did not change while the undated organic sediment was being deposited:

c) the core has at least two radiocarbon dates.

Then, a constant pollen influx is assumed and the deposition time is calculated by:

$\underline{\text { Avg. } \text { pollen conc. in undated section }}=$ Deposition time pollen influx

Then,

Dep. time $\times$ Thickness of undated section $=$ Age of section .

Thus, the age of the glacial contact is:

Basal date + Age of undated section $=$ Age of glacial contact.

This method is outlined by RICHARD et al. (1982).

A method in Part B is then used to estimate the age of the glacial sediments.

2. If pollen data are unavailable, but another sediment sample has been dated, the sedimentation rate above the basal date is calculated and used to estimate the age of the contact with glacial sediments. Then a method in Part B is used to estimate the age of the glacial sediments.

3. If the above data is not available, the date is classified as too young (Y3).

B. Adjustments for the age of the glacial sediments.

1. If glacial varves are present, they are counted and added to the basal date.

2. If glacial varves are absent, 100 years is added to the basal date to estimate the deglaciation time.

Note: The midpoint of the depth of a dated sample is used in the measurement of distances between it and other stratigraphic locations in a core.
If pollen data are unavailable but if another sediment sample was dated above the basal sample, the sedimentation rate between the two dates was extrapolated downward to calculate the number of years between the basal date and the glacial contact (A2, Table II). An example of this method is also given in Table III. This method probably overestimates the adjustment, as sedimentation rates were probably higher in the inorganic sediments.

No adjustment to a date was made if neither pollen data nor multiple radiocarbon dates are available for a core. Dates from such sites are thus younger than the local deglaciation time (Step 6c, Fig. 4).

The methods used above estimate the number of years represented by the undated organic sediment above the glacial sediments, but local deglaciation was in progress while the underlying inorganic glacial sediments were being deposited as well. So the age of these sediments should also be estimated and added to the estimated age of the glacial contact to produce the best estimate of the timing of local deglaciation.

TABLE III

Examples of corrections methods from Table /I

A1. Pollen Influx Correction

Site name: Lac au Sable, Site 32

Midpoint of basal date ${ }^{*}: 9.50 \mathrm{~m}$ Contact with glacial sediments: $9.58 \mathrm{~m}$

Base of core: $9.67 \mathrm{~m}$ Basal radiocarbon date: $6860+100$

Pollen influx at $9.48 \mathrm{~m}: 6.3 \times 10^{3} \mathrm{grns} / \mathrm{cm}^{2} / \mathrm{yr}$

Pollen concentration:

$9.48 \mathrm{~m} 2.74 \times 10^{5} \mathrm{grns} / \mathrm{cm}^{3} \quad$ Avg. pollen conc. $=$ $9.53 \mathrm{~m} 1.54 \times 10^{5} " \quad 2.14 \times 10^{5} \mathrm{grns} / \mathrm{cm}^{3}$

Deposition time:

$\frac{2.14 \times 10^{5} \mathrm{grns} / \mathrm{cm}^{3}}{6.1 \times 10^{3} \mathrm{grns} / \mathrm{cm}^{2} / \mathrm{yr}}=35.1 \mathrm{yr} / \mathrm{cm}$

Caiculation of adjustment:

$35.1 \mathrm{yr} / \mathrm{cm} \times 8 \mathrm{~cm}=281$ years

Adjustment for glacial sediments $(B 2)=100$ years

Total adjustment $=281+100=381$ years

Age of core base $=6860+381=7241 \mathrm{yr} \mathrm{BP}=7.2 \mathrm{~K}$

* all depths measured from the water surface

A2. Sedimentation Rate Correction

Site name: Whitney's Gulch, Site 1

Lowest two radiocarbon dates:

$6.70 \mathrm{~m} 8965 \pm 150 \quad 7.50 \mathrm{~m} 9820 \pm 150$

Contast with glacial sediments: $8.00 \mathrm{~m}$.

Sedimentation rate $=9820-8965 \mathrm{yrs}=10.7 \mathrm{yrs} / \mathrm{cm}$

$7.50-6.70 \mathrm{~m}$

Calculation of adjustment:

$50 \mathrm{~cm} \times 10.7 \mathrm{yrs} / \mathrm{cm}=535$ years

Adjustment for glacial sediments $(B 2)=100$ years

Age of core base $=9820+535+100=$

$10,455 \mathrm{yr} B \mathrm{P}=10.5 \mathrm{~K}$ 
The above method for estimating deposition time rates using pollen influx data was not applied to the inorganic sediments, as it is unlikely that the pattern of sedimentation in the basin was the same for both the organic and inorganic sediment types. For instance, a change in pollen concentration between the two sediment types could be attributed to changing patterns of pollen sedimentation rather than solely to changes in deposition time. Thus a different method must be used to adjust a date for the age of the glacial sediments. Also, sedimentation rates were not extrapolated into inorganic sediments, as the sedimentation rate of the inorganic sediments was probably much higher than that of the organic sediments. Instead, two alternative methods were used to estimate the age of the glacial sediments (Part B, Table II). Dates from directly above the glacial contact are also adjusted using one of these two methods, although they did not require an adjustment for undated organic sediments.

First, if glacial varves are present below the basal date, they were counted to date the glacial sediments (B1, Table II). Unfortunately, only one site in the data set has glacial varves (Site 16). So at all the other sites 100 years were added to the dates of the basal organic sediments, as this is probably the minimum number of years represented by the glacial sediments (B2, Table II). These sediments probably do not represent a period of more than 500 years, at least for dates younger than $8.0 \mathrm{~K}$, because once deglaciation began in the study area the local ice probably melted rapidly as the climate to the south was relatively warm after 8.0K (DAVIS et al., 1980; KING, 1986).

Empirical evidence supporting the above assertion about the number of years represented by the glacial sediments is found in Finland, where a varve date of ice retreat from the Salpausselka II end moraine gives an estimate of 10.2-10.3 yr BP for local deglaciation, while the oldest radiocarbon dates of the same event are between 10.0 and $10.2 \mathrm{yr} \mathrm{BP}$, a maximum difference of 3200 years (HYVÄRINEN, 1973).

Final acceptance of the corrected dates was based on a regional comparison of dates. Dates significantly older (Step $7 \mathrm{a}$, Fig. 4) or younger (Step 8a) than the regional pattern of deglaciation are not used in the reconstruction. Using a regional test for elimination of dates is somewhat unsatisfactory as the reason a date does not fit into the regional pattern is unknown, but in many cases it is the best that can be done with the available information. Dates deemed acceptable after this last step in their evaluation are used in the deglaciation reconstruction (Step 9, Fig. 4).

\section{Basal Peat Dates}

Peatlands are very common in the study area, and the basal peat layers of several mires have been dated to give estimates of local deglaciation time. However, several hundred to perhaps thousands of years may elapse between deglaciation and initiation of peat accumulation at a site, depending on such factors as climate, local vegetation, and local hydrology. In this study, all basal peat dates are considered younger than the local deglaciation time. However, in areas without any basal dates from limnic sediments, basal peat dates are used to give a minimum estimate of the local deglaciation time. One hundred years were added to these dates, as this was the minimum correction added to the lake sediment dates (B2, Table II).

\section{PROCEDURE FOR MAPPING ICE-MARGINAL POSITIONS}

All of the dates accepted for use in the reconstruction were plotted on a map of the study area. Some dates that were classified as being younger than the local deglaciation time were also used in the reconstruction if they are from areas where no other dates were available. Isochrones, representing the position of the retreating ice front, were then drawn to fit the chronological data and to be consistent with what is known about the region's glacial geology. The isochrones were drawn at intervals of 500,1000 , and 1500 years depending upon the amount of information available for a particular age. Dashed lines were used to indicate uncertainty in a isochrone's position.

\section{RESULTS}

The dates assembled for reconstructing the regional deglaciation history of southeastern Labrador-Ungava are summarized in the Appendix together with pertinent data on their location and evaluation. Dates used in the reconstruction are marked by an $\mathrm{X}$ in the table. The regional deglaciation chronology constructed from this data set is shown in Figure 5 and will be discussed by regional divisions of the study area.

\section{SOUTHEASTERN LABRADOR}

Deglaciation of the southeastern part of the Labrador-Ungava Peninsula began along the coast of southeastern Labrador, but where the Late Wisconsin ice margin was located and when ice retreat began from it are still under debate. Evidence from the marine record (VILKS and MUDIE, 1978; JOSENHANS, 1983; VILKS et al., 1984) indicates that Late Wisconsin ice did not extend past the present coast, although Early Wisconsin ice may have (JOSENHANS, 1983; VILKS et al., 1984). Moreover, foraminiferal and pollen data from two cores from the Cartwright Saddle off of Grosswater Bay have been interpreted as indicating that an extensive portion of southeastern Labrador was ice-free during Late Wisconsin time, specifically after 21.0K (VILKS and MUDIE, 1978). The vegetation growing in the ice-free area was interpreted as a densely vegetated sedge-shrub tundra (VILKS and MUDIE, 1978).

Key to this interpretation is the accuracy of the marine core dates. The sediments dated are very low in organic carbon, so contamination by older carbon could be a significant problem. A likely source of old carbon in this coastal area during deglaciation was glacial meltwater flowing out of Lake Melville. Recent comparisons of shell dates and total organic matter dates from marine cores in the Labrador Sea have shown that the latter dates can be several thousand years older than shell dates at the same stratigraphic location (FILLON et al., 1981). Thus the dates used to infer an ice-free southeastern Labrador may be too old, and corroborating evidence is needed to substantiate the interpretation of the marine record.

The glacial geology of southeastern Labrador unfortunately does not yield clear evidence for the location of the Late 


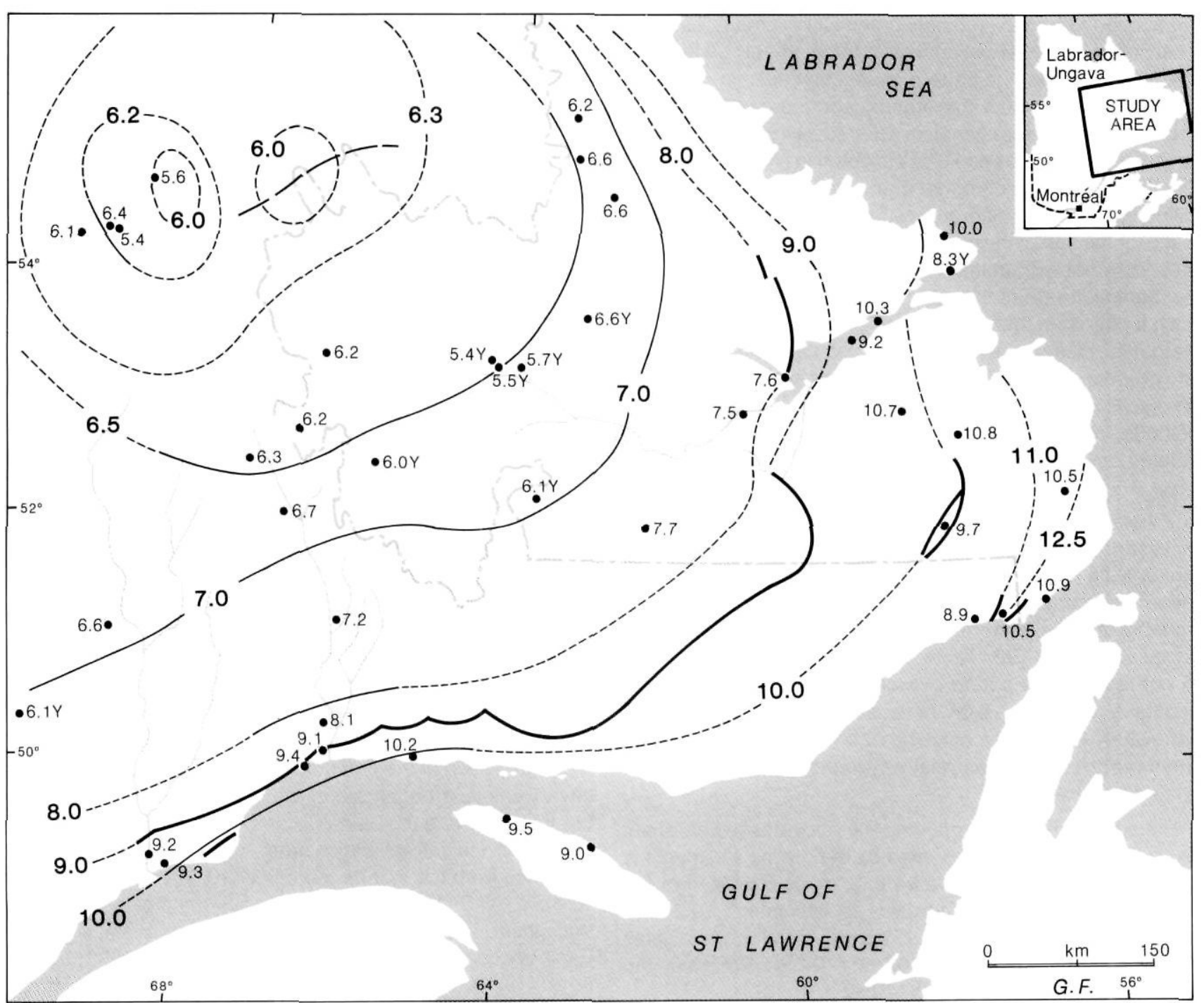

FIGURE 5. Deglaciation chronology for the study area. Dots indicate the location of the radiocarbon dates used to draw the isochrones; numbers next to them indicate the estimated local deglaciation time at the site in $1000 \mathrm{yr}$ BP. Dates followed by a $Y$ give only minimum dates of deglaciation. See Figure 1 for identification of the specific sites. The sub-glacial drainage divide of IVES (1960a) is indicated by long dashes. End-moraines are indicated by heavy solid lines. Uncertainty in the position of an isochrone is indicated by a dashed line.

Wisconsin ice margin. It may have been located at the Paradise Moraine, which trends northeast to southwest about $120 \mathrm{~km}$ inland (Fig. 1), and is characterized by dead-ice hummocky terrain (FULTON and HODGSON, 1979). The moraine may extend to the southwest all the way to the Gulf of St. Lawrence near the Mingan Islands (PREST, 1984).

East of the moraine evidence for glacial flow is sparse. The available evidence suggests that movement was to the southeast and not related to the Late Wisconsin ice flow west of the moraine, supporting the hypothesis that the Paradise Moraine did form the Late Wisconsin margin in the region. However, the ice could have been cold-based and non-erosive
Chronologie de la déglaciation dans la région à l'étude. Les points situent les éléments datés au radiocarbone et utilisés pour dresser les isochrones, ils sont accompagnés de chiffres qui donnent le moment de la déglaciation du site (en milliers d'années BP). Les dates suivies d'un $Y$ sont des seuils. (Se rapporter à la figure 1 pour connaître les sites de prélèvement.) Les longs tirets représentent la ligne de partage du drainage sous-glaciaire, selon IVES (1960a); les lignes grasses, les moraines frontales. Les tiretés reflètent une incertitude quant à la localisation des isochrones.

east of the moraine during this time and thus not have deposited glacial material (FULTON and HODGSON, 1979). Also, Late Wisconsin ice was present in Sandwich Bay (ROGERSON, 1981).

The age of the Paradise Moraine is crucial to the placement of the Late Wisconsin ice margin. Dating control of the moraine and the local deglaciation is provided by several basal dates of lake sediments (Sites 1-9, Appendix). First, the basal date from Moraine Lake located on the moraine (Site 4, ENGSTROM and HANSEN, 1985, Appendix) indicates that the moraine formed by $9.7 \mathrm{~K}$. Acceptance of this date would place the Late Wisconsin margin east of the moraine. Although Moraine 
Lake is an ice-block depression, a layer of macrofossils is absent from the base of the core, so there is no evidence of a buried ice block having persisted in the lake basin for a long period of time. The ice probably melted relatively fast and the basal date is thought to be a reasonable estimate, although probably a slight underestimate, of the age of the Paradise Moraine.

Second, basal dates east of the moraine are consistently younger than $11.0 \mathrm{~K}$ except for those Alexis Lake (Site 9, LAMB, 1978, Appendix). Basal dates from this lake range from $8.6 \mathrm{~K}$ to $28.9 \mathrm{~K}$. Acceptance of these dates would corroborate the marine evidence and place the Late Wisconsin ice margin along the Paradise Moraine. However, the dates from this core are probably highly inaccurate, as they are from sediments very low in organic carbon. Old carbon from the retreating ice could have contaminated the sediments and resulted in the old dates. Furthermore, some of the dates do not fall in stratigraphic sequence. Thus the dates from Alexis Lake were not used in the construction of the deglaciation chronology. The remaining dates, which are consistent, indicate that most of southeastern Labrador was ice-covered until about 11.0K.

Additional geological evidence for the location of the LateWisconsin ice margin comes from extreme eastern Québec, where two moraines, the Belles Amours Moraine, formerly the Brador Moraine of GRANT (1969a), and the new Brador Moraine (GRANT, in press), are located southeast of the Paradise Moraine (Fig. 1). The age of the moraines is uncertain. A date in front of the Belles Amours Moraine is at least $10.5 \mathrm{~K}$ (Site 1, LAMB, 1980, Appendix). DUBOIS (1977) considers the Belles Amours Moraine to correlate with the Ten Mile Lake advance in Newfoundland at 11.0-10.9K, and GRANT (in press) considers the Brador Moraine to correlate with the Piedmont Moraine in Newfoundland, which dates between 12.7 and 12.6K (GRANT, 1969b). Acceptance of these dates and correlations would place the Late Wisconsin ice margin east of the Paradise Moraine.

To summarize, the position of the Late Wisconsin ice margin in southeastern Labrador is not certain, although the presence of the Belles Amours and Brador Moraines and the consistent basal lake sediment dates of less than $11.0 \mathrm{~K}$ east of the Paradise Moraine (excluding the Alexis Lake dates) suggests that the Late Wisconsin ice margin was east of the Paradise Moraine. However, marine evidence indicates that it was not beyond the present coast. Therefore extreme southeastern Labrador is considered to have been ice-free during Late Wisconsin time with the ice margin perhaps located along the Brador Moraine (DUBOIS and DIONNE, 1985). Ice retreat from the Late-Wisconsin maximum began slowly, perhaps about $13.0 \mathrm{~K}$. The $12.5 \mathrm{~K}$ isochrone is drawn at the Brador Moraine, and the $11.0 \mathrm{~K}$ isochrone is anchored at the Belles Amours Moraine (Fig. 5).

\section{SEPT-ÎLES}

The deglaciation history of the Sept-îles area is better known in certain respects than that in southeastern Labrador, although the chronology of events is still uncertain. Late Wisconsin ice appears to have extended south of the present coastline to about the $300 \mathrm{~m}$ bathymetric contour (DREDGE, 1983) and to the south coast of the western part of Anticosti Island (PAINCHAUD, et al., 1984). Retreat of the ice from its maximum extent began about $13.5 \mathrm{~K}$, although the Québec North Shore in this region was not deglaciated until $10.2 \mathrm{~K}$, according to a marine-shell date east of Sept-îles (Site 13, DUBOIS, 1977, Appendix).

Southwest of Sept-Îles the Baie-Trinité minor moraine formed just inland to the coast after deglaciation (Fig. 1). Although the moraine is undated, shell dates of 9.2 and $9.3 \mathrm{~K}$ just inland to it (Sites 17, 1i, DUBOIS, 1977; SAUVÉ and LASALLE, 1968) estimate its minimum age. Regional correlations suggest the moraine formed before the coast at site 13 was deglaciated at 10.2K (DREDGE, 1983), and the moraine may be contemporaneous with the Paradise Moraine. DUBOIS (1980, as cited in DUBOIS and DIONNE, 1985) estimates the age of the moraine to be between $10.3 \mathrm{~K}$ and $10.0 \mathrm{~K}$. The $10.0 \mathrm{~K}$ isochrone is thus placed just inland to the Baie-Trinite moraine, extends east-northeast from there, and curves northeastwards to connect with the Paradise Moraine (Fig. 5).

Finally, the immediate vicinity around Sept-Îles region was the last part of the Québec North Shore to become ice-free at about 9.4K (Site 15, DUBOIS, 1977, Appendix).

When the ice margin retreated up onto the Laurentide Massif north of Sept-îles and reached the marine limit of 130 $\mathrm{m}$, the Lac Daigle moraine was formed. The moraine forms part of the Québec North Shore Moraine System that stretches $800 \mathrm{~km}$ from the Manicougan River $\left(49^{\circ} 25^{\prime} \mathrm{N}, 68^{\circ} 30^{\prime} \mathrm{W}\right)$ to the Kenamu River $\left(52^{\circ} 50^{\prime} \mathrm{N}, 60^{\circ} 38^{\prime} \mathrm{W}\right.$ ) (Fig. 1, DUBOIS and DIONNE, 1985). The four major segments that make up the moraine system vary in width from a few hundred meters to $4 \mathrm{~km}$ and have an average drift thickness of 10 to $20 \mathrm{~m}$ (DUBOIS, 1977, 1979; DREDGE, 1976a,b; FULTON and HODGSON, 1979). These segments include major till ridges, series of parallel ridges, outwash plains, and dead-ice hummocky morainic deposits (DUBOIS and DIONNE, 1985).

The Québec North Shore Moraine System is of major importance in determining the deglaciation history of the region, as it marks the position of the ice at an intermediate stage of deglaciation, assuming the four segments are contemporaneous (DUBOIS and DIONNE, 1985). For instance, it clearly shows that the Sept-Îles region was deglaciated after most of southeastern Labrador was ice-free. Thus dating this moraine is critical in determining the regional deglaciation chronology

The only dates relating directly to the age of the Québec North Shore Moraine System come from the Sept-îles area. Interfingerings of till, outwash, and beach sand just south of the Lac Daigle moraine suggest that the moraine formed when the Goldthwait Sea was at its maximum level (DREDGE, 1976a; DIONNE, 1977). Thus marine shell dates of 9.4K (Site 15, DUBOIS, 1977, Appendix) and 9.7K (QU-214, DUBOIS and DIONNE, 1985) apparently date the Lac Daigle moraine and the rest of the Québec North Shore Moraine System (DUBOIS and DIONNE, 1985).

An additional clue to the age of the moraine is the distribution of Goldthwait Sea sediments in relationship to the moraine. 
Marine deposits have been found $70 \mathrm{~km}$ north of the Lac Daigle moraine in some of the major river valleys in the region at elevations up to $125 \mathrm{~m}$, which is just below the maximum marine limit in the area of $130 \mathrm{~m}$ (DREDGE, 1976a; DUBOIS 1977), Thus, ice retreated from the Québec North Shore Moraine System while the Goldthwait Sea was near its maximum level in the area; about $9.0 \mathrm{~K}$ if the dates are correct.

Two problems develop when this date of the Québec North Shore Moraine System is compared with other regional events. First, a basal date from Lac Pétel located north of the moraine (Fig. 1; Site 16, KING, 1986, Appendix), is $8.1 \mathrm{~K}$, indicating that perhaps the moraine system only dates to $8.3 \mathrm{~K}$. Second, recent work by PAINCHAUD et al. (1984) demonstrates that ice from the north formed the Rivière à l'Huile Moraine on the northwest margin of Anticosti Island between 9.0 and 9.5K (Sites 11, 12, Appendix). The Québec North Shore Moraine System must be younger than this ice advance, so the dating of both moraines is uncertain.

A possible reason for the conflict between the Lac Pétel date and the Québec North Shore Moraine System dates is that the Lac Pétel date is from lake sediment whereas the Québec North Shore Moraine System dates are from marine shells. Perhaps the apparent age of the ocean water present along the Québec North Shore during deglaciation was much greater than 410 years because of the influx of glacial meltwater, and thus the marine shell dates from this area and time period are older than their true radiocrabon age. If this is the case the Québec North Shore Moraine System may date more closely to $9.0 \mathrm{~K}$ than $10.0 \mathrm{~K}$.

Resolution of the conflict between the dates of the Québec North Shore Moraine System and the dates of the Rivière à l'Huile Moraine is not possible at this time, other than to say that the Rivière à l'Huile Moraine may date between 10.5 and $11.0 \mathrm{~K}$ and must have formed prior to the formation of the Québec North Shore Moraine System and probably the Paradise Moraine.

In summary, perhaps the Québec North Shore Moraine System dates more closely to $9.0 \mathrm{~K}$ than $10.0 \mathrm{~K}$ assuming the dates from the marine shells are too old and the Lac Pétel date is reasonably accurate. The $9.0 \mathrm{~K}$ isochrone is drawn along the moraine, although its placement there is tenuous (Fig. 5). Additional information on the age of the Québec North Shore Moraine System is present near Goose Bay, Labrador, as is discussed in the next section. In any case, additional dates from either side of the moraine are needed to determine its age more precisely. The Lac Pétel date of $8.1 \mathrm{~K}$ suggests that ice remained in the highlands north of Sept-îles for perhaps 1000 years after $9.0 \mathrm{~K}$. It forms an anchor for the $8.0 \mathrm{~K}$ isochrone in the southwestern part of the study area.

\section{LAKE MELVILLE REGION}

This region includes the Lake Melville Depression (Fig. 2) and the areas immediately to the north and south. Glacial features are very common in this area, and only those directly relating to the regional pattern of deglaciation are discussed.
Late Wisconsin ice stretched all the way to the coast north of Lake Melville and filled Grosswater Bay until about 10.0K, as interpreted from a marine shell date at the mouth of the Michael River (Site 20, HODGSON and FULTON, 1972; FULTON and HODGSON, 1979; Appendix). Ice retreat from the coast proceeded westwards north of the lake and up the Lake Melville Depression. Two dates give estimates of the ice marginal position during its retreat up the basin. A date of $10.2 \mathrm{~K}$ from Saint John Island Pond (Site 21, JORDAN, 1975, Appendix) may indicate the deglaciation of the eastern part of the basin, but the large standard deviation of the date, 1200 years, make the date unreliable. The second date, a downward extrapolation of the sedimentation rate in a marine core from the middle of the basin, indicates that the channel was icefree by about 9.2K (Site 22, VILKS and MUDIE, 1983, Appendix).

At the west end of Lake Melville numerous small moraines and ice-directional features indicate the local pattern of ice retreat. During the latter stages of deglaciation in the area, extensive drawdown of the ice occurred through the Lake Melville Depression. This changed the flow pattern of ice southwest of Goose Bay from the regional southeasterly flow to a northeasterly flow. The area north of Lake Melville was not noticeably affected by the drawdown, while to the south the Little Drunken Moraine (Fig. 1) formed as a direct result of it (FULTON and HODGSON, 1979). This moraine is the northeastern segment of the Québec North Shore Moraine System (DUBOIS and DIONNE, 1985).

From the local pattern of deglaciation and dates of ice retreat from western Lake Melville it is possible to approximate the age of the Little Drunken Moraine and hence the northern part of the Québec North-Shore Moraine System. The Little Drunken Moraine is younger than the Paradise Moraine and the retreat of the ice from Grosswater Bay, indicating that its maximum age is less than $10.0 \mathrm{~K}$. The moraine also formed after drawdown of the ice near Goose Bay had begun, probably after the ice retreated past the middle of the Lake Melville Depression at about 9.2K. A minimum age for the moraine is $7.5 \mathrm{~K}$, by which time ice had retreated to Muskrat Falls on the Churchill River (Site 24, LOWDON and BLAKE, 1975, Appendix). Thus the moraine dates between 9.2 and $7.5 \mathrm{~K}$, which is consistent with the information from the Sept-îles area and the placement of the $9.0 \mathrm{~K}$ isochrone (Fig. 5).

When the ice margin reached the west end of Lake Melville it was composed of four principal sublobes. One sublobe extended down the Grand Lake Basin and into the Lake Melville Depression, forming a trough. The other lobes were centered in the Churchill River valley (GRANT, 1971). Retreat of the Grand Lake ice lobe resulted in the formation of several minor moraines near the town of North West River (BLAKE, 1956; GRANT, 1971). The minor moraine running through North West River has a minimum age of 7.6K (Site 23, LOWDON and BLAKE, 1980, Appendix). Another minimum date for this moraine is the $7.5 \mathrm{~K}$ date from Muskrat Falls. The Sebaskachu Moraine, located just northeast of North West River, 100 km long, and trending north-south (Fig. 1; FULTON and HODGSON, 1979), is probably contemporaneous with the aforementioned minor moraine. 
Thus the 8.0K ice margin was located near Goose Bay and the 8.0K isochrone is drawn parallel to the Québec North Shore Moraine System and along the Sebaskachu Moraine, which probably formed at about 8.0K.

\section{INTERIOR LABRADOR AND ADJACENT QUÉBEC}

Long end moraines north of the Québec North Shore Moraine System have yet to be identified or are not present in the region, so the positions of the deglaciation isochrones in the interior are based solely on basal dates of lake sediments. Exceptions to this are the positions of the final centers of ice wastage, as discussed in the next section.

The position of the $7.0 \mathrm{~K}$ isochrone is reasonably well controlled with twelve dates relatively evenly distributed through the region (Fig. 5, Sites 23, 24, 30-32, 34-36, 44-47, Appendix). The $6.5 \mathrm{~K}$ isochrone is added because of the numerous dates available from western Labrador.

Another indication of the extent of the ice sheet in the interior through time is the rate of sedimentation in river deltas along the coasts. Sediments in the Rivière Moisie delta near Sept-îles were deposited rapidly after deglaciation until about 7.0K, indicating that most of the ice in its drainage basin had melted by then (DREDGE, 1983). The Rivière Moisie extends north to the Québec-Labrador border just south of Labrador City. The $7.0 \mathrm{~K}$ isochrone as drawn runs through the upper part of the Rivière Moisie drainage area and thus is consistent with the sedimentation record at the river delta. Sedimentation rates remained high in Lake Melville until 5.0K, which is also consistent with the glacial and vegetation history of the region (VILKS and MUDIE, 1983).

By 7.0K, the center of the ice sheet may have been situated along the northwest to southeast trending ice-divide located west of Schefferville (Fig. 1, HUGHES, 1964). Late Wisconsin ice flow near Churchill Falls, Labrador (Fig. 1), was eastward to southeastward (BOLDUC and KLASSEN, 1984), which is consistent with the Late Wisconsin ice center being west of Schefferville and the placement of the $7.0 \mathrm{~K}$ isochrone.

\section{FINAL WASTAGE OF THE LAURENTIDE ICE}

After $6.5 \mathrm{~K}$ ice retreat proceeded rapidly. Late-glacial features in the central part of the peninsula show that as the ice sheet thinned it became divided into two independent masses (IVES, 1960a,b; HUGHES, 1964; RICHARD et al., 1982). An ice divide trending southwest-northeast, located $35 \mathrm{~km}$ northnorthwest of Schefferville, indicates the position of one of the ice masses (IVES, 1960a). However, the ice-divide is really a subglacial water-divide, and flow from this ice center was never significant. The other ice mass was centered along the ice divide located west of Schefferville, mentioned above (Figs. 1,5, HUGHES, 1964). When the ice separated into two masses in uncertain, but it was probably after 6.3K. A possible configuration of the ice at this time is shown in Figure 5.

Dating the final wastage of the easternmost ice cap has proven to be a problem. Several dates of basal lake sediments in this region (Site 54-57, Appendix) are older than 8.0K, clearly too old considering the regional pattern of deglaciation. These dates are from sediments that were probably contam- inated by old carbon according to STRAVERS (1981), who concludes that the oldest reliable date in her study is $6.7 \mathrm{~K}$ from Boundary Lake (Site 57, STRAVERS, 1981, Appendix). This date is also relatively old, so it is uncertain when ice finally melted from this area. It was probably closer to $6.0 \mathrm{~K}$ than $7.0 \mathrm{~K}$ judging from other nearby dates. A dashed line circling the ice divide is drawn to indicate that some ice probably remained there until at least 6.0K (Fig. 5).

The sequence of events in the wastage of the remnant ice cap farthest west of Schefferville is reasonably well-known. Final stagnation of the ice occurred about $6.2 \mathrm{~K}$ when the southwest margin of the ice was located $25-35 \mathrm{~km}$ southwest of the ice divide (RICHARD et al., 1982). The maximum diameter of the ice cap was centered along the ice-divide at this time (HUGHES, 1964) and an approximate outline of the $6.2 \mathrm{~K}$ ice margin is drawn in Figure 5 . The date of $6.2 \mathrm{~K}$ for final stagnation conflicts with the $6.4 \mathrm{~K}$ date from Lac Delorme II, which was located within the ice margin at this time, although it is within the counting error of the date (Site 61, RICHARD et al., 1982, Appendix).

Continued ablation of ice resulted in the southwestern margin of the ice cap retreating into the highlands northeast of the ice-divide. Ice persisted there until about 5.6K (Site 59, RICHARD et al., 1982, Appendix). The 6.0K isochrone is drawn around this site only to indicate that some ice remained in this area at that time.

\section{DISCUSSION}

\section{PRECISION OF THE ISOCHRONES}

The precision of each isochrone varies with the amount of information used to map its position. Some of the uncertainty in the placement of the isochrones is indicated in Figure 5 by the dashed lines. A discussion of the relative precision of each isochrone is presented below.

The $12.5 \mathrm{~K}$ isochrone is based only on the correlations of the Belles Amours Moraine with the Piedmont Moraine in Newfoundland (GRANT, in press). It is undated along the rest of its length. Similarily the position of the $11.0 \mathrm{~K}$ isochrone is uncertain, but it appears that the ice did not retreat very far between $12.5 \mathrm{~K}$ and $11.0 \mathrm{~K}$.

In contrast, the Paradise Moraine provides information on the location of the ice margin early in its retreat. Dates east of the moraine and on top of it indicate that the moraine formed between $9.7 \mathrm{~K}$ and $10.5 \mathrm{~K}$. Unfortunately no dates are available immediately west of the moraine to corroborate this estimate. The $10.0 \mathrm{~K}$ isochrone is placed along the moraine.

The positions of the $9.0 \mathrm{~K}$ and $8.0 \mathrm{~K}$ isochrones are the least well documented. The uncertainty in the age of the Québec North Shore Moraine System makes the placement of the $9.0 \mathrm{~K}$ isochrone tenuous. The moraine definitely dates between $8.1 \mathrm{~K}$ and $9.4 \mathrm{~K}$; a date of $9,0 \mathrm{~K}$ is assumed here and the $9.0 \mathrm{~K}$ isochrone is drawn along the moraine. Despite the uncertainty of the moraine's age, it provides another benchmark for the location and shape of the ice margin during its retreat. The position of the $8.0 \mathrm{~K}$ isochrone is uncertain because of the paucity of $8.0 \mathrm{~K}$ basal dates. Dates near Goose Bay and 
at Lac Pétel north of Sept-Îles anchor the isochrone just interior to the Québec North Shore Moraine system.

In contrast, the $7.0 \mathrm{~K}$ and $6.5 \mathrm{~K}$ isochrones are better controlled, with 12 dates providing the chronological and geographical control of the $7.0 \mathrm{~K}$ isochrone, and 11 dates between 6.0 and $7.0 \mathrm{~K}$ controlling the 6.5 isochrone.

The $6.3 \mathrm{~K}, 6.2 \mathrm{~K}$, and $6.0 \mathrm{~K}$ isochrones are drawn to indicate the pattern of final ice wastage rather than the precise location of the ice margin at the indicated times. Thus the $6.3 \mathrm{~K}$ isochrone is drawn to approximate the likely configuration of the ice before it separated into two distinct bodies, and the $6.2 \mathrm{~K}$ isochrone is drawn to indicate the approximate size and location of the westernmost ice cap when final stagnation of the ice took place. The $6.0 \mathrm{~K}$ isochrones are meant only to show that some ice still remained in the region at this time.

Even if more dates from the region meeting the requirements set forth in this paper for use in the reconstruction become available, there is a limit to the precision with which an isochrone can be drawn because of counting errors in the determination of the ${ }^{14} \mathrm{C}$ activity of a sample. Thus each basal date is not precisely known and is best represented by a two standard deviation range about it (e.g. BLAKE, 1983). As these dates are used to control the positions of the isochrones, the isochrones have at least the same amount of variability as the basal dates. One way to estimate the spatial variability of an isochrone from its chronological variability is to multiply the average counting error of the dates used to control the location of the isochrone by the estimated rate of ice retreat at that time:

Precision of $=$ Avg. counting error $\times$ Estimated rate of (1) an isochrone of dates used to ice retreat draw an isochrone

For example, the $7.0 \mathrm{~K}$ isochrone was drawn using 12 dates. The average counting error of the these dates is \pm 120 years. The average rate of retreat at this time was estimated to be $180 \mathrm{~m} / \mathrm{yr}$ by calculating the average distance the ice retreated between the 7.0 and $6.5 \mathrm{~K}$ isochrones and dividing by 500 years. Multiplying this number by the average counting error gives $\pm 22 \mathrm{~km}$. Thus the spatial precision of the $7.0 \mathrm{~K}$ isochrone is estimated to be no better than $\pm 22 \mathrm{~km}$.

Realistically the precision of the isochrones is not limited by the counting errors in radiocarbon dating but by biases in the dates introduced through the sampling procedure. Equation 1 should thus be modified in the following way:

\begin{tabular}{|c|c|}
\hline $\begin{array}{l}\text { Estimated } \\
\text { precision of } \\
\text { an isochrone }\end{array}$ & $\begin{array}{l}=\text { Estimated precision } \times \text { Estimated rate of } \\
\text { of deglaciation } \quad \text { ice retreat } \\
\text { dates used to } \\
\text { draw the } \\
\text { isochrone }\end{array}$ \\
\hline
\end{tabular}

To determine how much a given amount of uncertainty in the estimated deglaciation times at individual sites will affect the precision of the isochrones, varying estimates of the uncertainty of basal radiocarbon dates and ice retreat rates were substituted into equation 2 and the results tabulated in Table IV. Boundary conditions in the table are \pm 100 years and \pm 500 years for estimates of the precision of the deglaciation times, and es-
TABLE IV

Estimated precision of isochrones

\begin{tabular}{crrrrrrrrr}
\hline $\begin{array}{c}\text { Average Rate of } \\
\text { Ice Retreat } \\
\text { (km/year) }\end{array}$ & \multicolumn{8}{c}{ Precision of dates (years) } \\
\cline { 2 - 8 } & \pm 100 & 120 & 150 & 200 & 250 & 300 & 400 & 500 \\
\hline 10 & \pm 10 & 12 & 15 & 20 & 25 & 30 & 40 & 50 \\
.12 & 12 & 14 & 18 & 24 & 30 & 36 & 48 & 60 \\
.15 & 15 & 18 & 23 & 30 & 38 & 45 & 60 & 75 \\
.18 & 18 & 22 & 27 & 36 & 45 & 54 & 72 & 90 \\
.20 & 20 & 24 & 30 & 40 & 50 & 60 & 80 & 100 \\
.25 & 25 & 30 & 38 & 50 & 63 & 75 & 100 & 125 \\
.30 & 30 & 36 & 45 & 60 & 75 & 90 & 120 & \pm 150 \\
\hline
\end{tabular}

timated retreat rates range from 100 to $300 \mathrm{~m} / \mathrm{yr}$. The range in the estimated precision under these conditions is \pm 10 to $\pm 150 \mathrm{~km}$.

The boundary conditions for the precision of the basal radiocarbon dates represent the best and worst values that might be expected in a study of this type. The value of \pm 100 years means events greater than 200 years apart can be resolved, which J. KING et al. (1983) suggest is the finest resolution one can obtain in studies of lake sediments from the same region. The value of 500 years represents conditions of very poor resolution of events. The deglaciation rates are taken from DUBOIS (1979), who reviewed the rates of ice retreat from various parts of North America.

For this study perhaps the average precision in estimating the deglaciation times at sites is \pm 150 years, and ice retreat rates may average $150 \mathrm{~m} / \mathrm{yr}$ (DUBOIS, 1979), so the theoretical precision of isochrones based on a sufficient number of dates, on average, is about $\pm 23 \mathrm{~km}$ (Table IV). Isochrones that are not well-dated, such as the $8.0 \mathrm{~K}$ isochrone, have a higher level of uncertainty. Using $\pm 23 \mathrm{~km}$ as the estimated precision of the isochrones, another deglaciation map was drawn illustrating the spatial variability of the isochrones (Fig. 6).

From the map it can be observed that neither the 12.5 and $11.0 \mathrm{~K}$ isochrones nor the 9.0 and $8.0 \mathrm{~K}$ isochrones can be resolved, because the range of their possible positions, drawn using the estimated precision of the isochrones, overlap (Fig. 6). However, although average retreat rates for the ice margin can be calculated, the retreat of the ice was not steady but varied and stopped at certain times, as is evident from the end moraines in the study area. Varying ice retreat rates will affect the theoretical precision of the isochrones (see Equation 2), with slower ice retreat rates resulting in better precision of the isochrones. Since the ice retreat was slow between 12.5 and $11.0 \mathrm{~K}$ and between 9.0 and $8.0 \mathrm{~K}$, the precision estimates for these isochrones should be theoretically lower (e.g. more precise) than that calculated above. Nevertheless, Figure 6 is an attempt to show visually some of the spatial variability present in the isochrones.

\section{EVIDENCE OF CLIMATIC CHANGE FROM THE REGIONAL PATTERN OF DEGLACIATION}

The formation of the major end moraines in the study area may have been caused by significant changes in the regional 


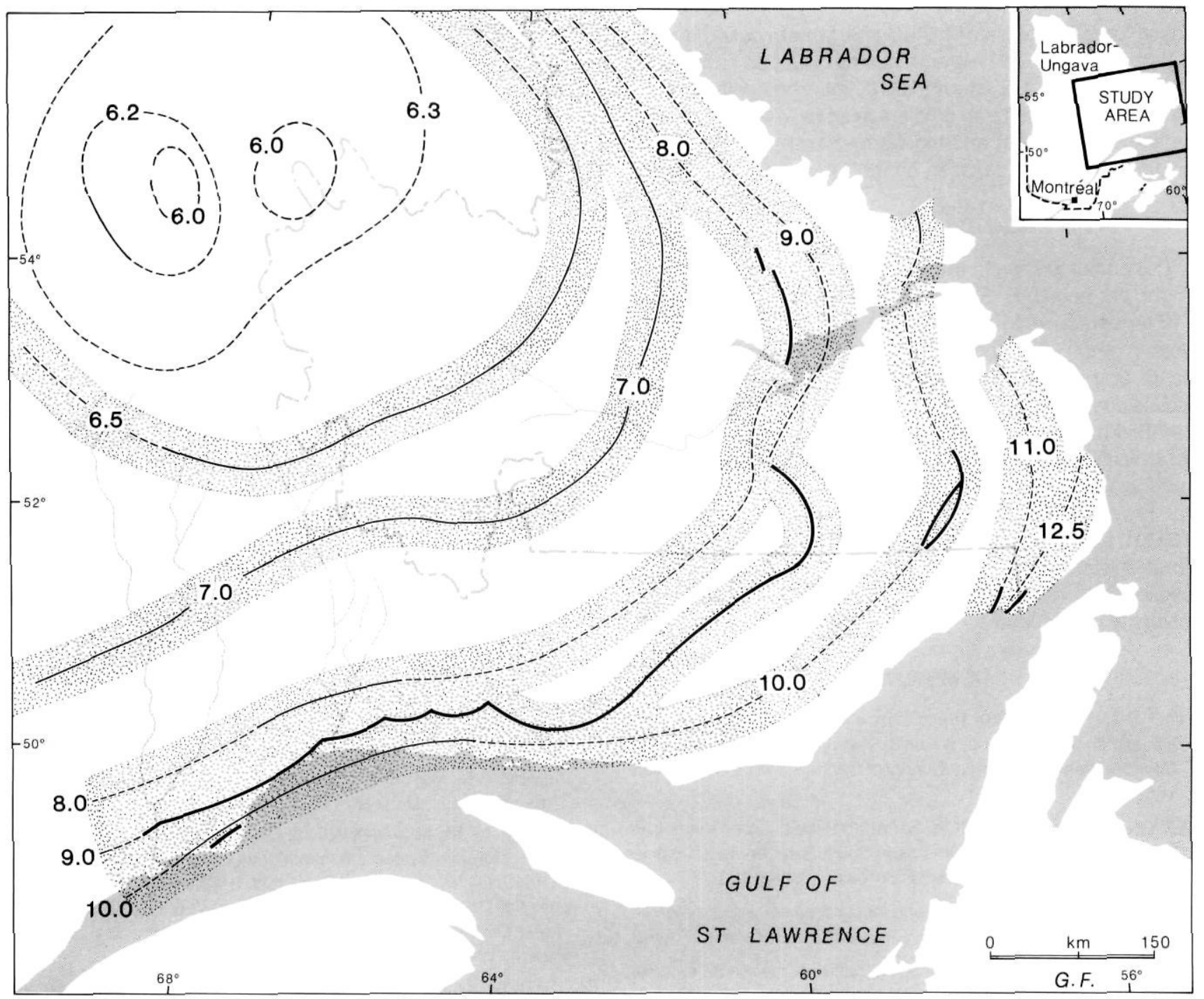

FIGURE 6. Deglaciation chronology of the study area, with the estimated precision of the isochrones $( \pm 23 \mathrm{~km})$ shown as shaded regions about them. The precision of the $6.3 \mathrm{~K}, 6.2 \mathrm{~K}$ and $6.0 \mathrm{~K}$ isochrones is not shown, as these isochrones are meant to only show the pattern of final ice wastage rather than the actual position of ice at these times.

climate. For instance, the Paradise Moraine may have been formed as a result of regional climatic cooling caused by the marked cooling of the North Atlantic between 11.0 and $10.0 \mathrm{~K}$ (RUDDIMAN and McNINTRYE, 1981). That this had a climatic impact in the region is suggested by pollen evidence from Newfoundland, where shrub tundra was replaced by herb tundra for a short period prior to 10.7K (ANDERSON, 1983). Perhaps the Paradise Moraine is the equivalent of a Younger Dryas event in North America. HILLAIRE-MARCEL and OCCHIETTI (1980) previously suggested that the closely spaced isochrones between 11.0 and $10.0 \mathrm{~K}$ in their deglaciation chronology indicate a cooling period at this time, possibly correlating with the Younger Dryas.

Whether the emplacement of the Québec North Shore Moraine System is a climatic event or not is uncertain. It may be a re-equilibration moraine, forming when calving ice reached
Chronologie de la déglaciation dans la région à l'étude. Le grisé représente le degré de précision de part et d'autre des isochrones $( \pm 23 \mathrm{~km})$. Rien n'est indiqué pour les isochrones de 6,3K,6,2K et $6,0 K$, qui illustrent le mode de disparition des glaciers et non la localisation exacte du front glaciaire.

the Québec North Shore (HILLAIRE-MARCEL and OCCHIETTI, 1980). However, it seems unlikely that the entire length of the moraine formed by this mechanism, and in fact the Little Drunken Moraine apparently formed as a result of drawdown into the Lake Melville basin (FULTON and HODGSON, 1979). Still, drawdown is a non-climatic mechanism for moraine formation, and thus there is a strong possibility that the separate segments of the Québec North Shore Moraine System formed by non-climatic mechanisms. To the contrary, DUBOIS and DIONNE (1985) argue that since the moraine system is so lengthy it likely formed as a result of a climatic deterioration over the southern part of the Labrador-Ungava Peninsula.

Although regional climatic patterns probably influenced the pattern of ice retreat in the study area, the remnant ice sheet may have also affected the local climate. For example, exten- 
sive ice still persisted in the study area as late as $6.5 \mathrm{~K}$, while closed forests of balsam fir (Abies balsamea) covered southeastern Labrador and extreme eastern Québec between 7.0 and 6.5K (ENGSTROM and HANSEN, 1985; KING, 1986). Thus a steep temperature gradient must have existed between the waning ice sheet and the warmer areas to the south at this time, most likely caused by the remnant ice sheet.

\section{ACKNOWLEDGEMENTS}

The author wishes to thank M. Kelleher, A. Loiselle, H. E. Wright, Jr., and D. R. Foster for assistance in the field work, T. W. Anderson, J. M. M. Dubois, D. R. Engstrom, M. V. Santelmann, and $H$. E. Wright, Jr. for critical reviews of the manuscript, and all of the above and W. Blake, Jr. for many helpful discussions leading to the great improvement of this paper. Wes Blake and the Radiocarbon Dating Laboratory at the Geological Survey of Canada kindly provided the basal dates from the lakes cored as part of this study. Financial support was provided by the National Science Foundation (DEB 8109901, DPP 810024), the U.S. Department of Energy through Brown University (DE-AC02-79EV), and a Doctoral Dissertation Fellowship to the author from the Graduate School at the University of Minnesota.

\section{REFERENCES}

ANDERSON, T. W. (1983): Preliminary evidence for Late Wisconsin climatic fluctuations from pollen stratigraphy in Burin Peninsula, Newfoundland, Geological Survey of Canada, Paper 83-1B: 185 188.

BJÖRCK, S., and HAKANSSON, S. (1982): Radiocarbon dates from Late Weichselian lake sediments in South Sweden as a basis for chronostratigraphic subdivision, Boreas, 11: 141-150.

BLAKE, W. Jr. (1956) : Landforms and topography of the Lake Melville, area, Labrador, Newfoundland, Geographical Bulletin, 9: 75-100.

(1983): Geological Survey of Canada radiocarbon dates XXIII, Geological Survey of Canada, Paper 83-7.

BOLDUC, A. M., and KLASSEN, R. A. (1984): Quaternary history of the Churchill Falls region, Labrador, Abstracts, 5th AQQUA Congress, Sherbrooke, Québec, p. 19-20.

BROECKER, W. S., GERARD R., EWING, M., and HEEZEN, B. (1960): Natural radiocarbon in the Atlantic Ocean, Journal of Geophysical Research, 65: 2903-2931.

BRYSON, R. A., WENDLAND, W. M., IVES, J. D., and ANDREWS, J. T. (1969): Radiocarbon isochrones on the disintegration of the Laurentide Ice Sheet, Arctic and Alpine Research, 1: 1-14.

DAMON, P. E., LONG, A., and GREY, D. C. (1970): Arizona radiocarbon dates for dendrochronologically dated samples, in OLSON, I. V. (edit.), Proceedings of the Twelfth Nobel Symposium on Radiocarbon Variations and Absolute Chronology, 1969, Almqvist and Wiksell, Forlag AB, Stockholm, p. 615-618.

DAVIS, M. B., and FORD, M. S. (1982): Sediment focusing in Mirror Lake, New Hampshire, Limnology and Oceanography, 27: 137150.

DAVIS, M. B., SPEAR, R. W., and SHANE, L. C. K. (1980): Holocene climate of New England, Quarternary Research, 14:240-250.

DEAN, W. E. (1974): Determination of carbonate and organic matter in calcareous sediments and sedimentary rocks by loss on ignition: comparison with other methods, Journal of Sedimentary Petrology, 44: 242-248

DEEVEY, E. S., GROSS, M. S., HUTCHINSON, G. E., and KRAYBILL, H. L. (1954): The natural C14 content of materials from hardwater lakes, Proceedings of the United States National Academy of Science, 40: 285-288.

DIONNE, J.-C. (1977): La mer de Goldthwait au Québec, Géographie physique et Quaternaire, 31: 61-80.

DREDGE, L. A. (1976a): The Goldthwait Sea and its sediments: Godbout-Sept-Îles Region, Québec North Shore, Geological Survey of Canada, Paper 76-1C: 179-181.

(1976b): Moraines in the Godbout-Sept-Îles area, Québec North Shore, Geological Survey of Canada, Paper 76-1C: 183184

(1983) : Surficial geology of the Sept-îles area, Québec North Shore, Geological Survey of Canada, Memoir 408.

DRISCOLL, F. G., Jr. (1980): Wastage of the Klutlan ice-cored moraines, Yukon Territory, Canada, Quarternary Research, 14: 3149.

DUBOIS, J. M. M. (1977): La déglaciation de la Côte Nord du SaintLaurent: analyse sommaire, Géographie physique et Quaternaire, 31: 229-246.

- (1979): Télédétection, cartographie et interprétation des fronts glaciaires sur la Côte Nord du Saint-Laurent entre le lac SaintJean et le Labrador, Bulletin de Recherche, Département de Géographie, Université de Sherbrooke, No. 42, 33 p.

(1980): Environnements quaternaires et évolution postglaciaire d'une zone côtière en émersion en bordure sud du Bouclier canadien: la Moyenne Côte Nord du Saint-Laurent, Québec, Thèse de Ph.D., Université d'Ottawa, 754 p.

DUBOIS, J. M. M. and DIONNE, J. C. (1985): The Québec North Shore Moraine System: A major feature of Late Wisconsin, in BORNS, H. W., Jr., LASALLE, P., and THOMPSON, W. B., (edit.), Late Pleistocene History of Northeastern New England and adjacent Quebec. The Geological Society of America Special Publication, 197 (in press).

ENGSTROM, D. E., and HANSEN, B. C. S. (1985): Vegetational change and soil development in southeastern Labrador as inferred from pollen and chemical stratigraphy, Canadian Journal of Botany, 63: 543-561.

FILLION, R. H., HARDY, I. A., WAGNER, F. J. E., ANDREWS, J. T., and JOSENHANS, H. W. (1981): Labrador Shelf: shell and total organic matter ${ }^{14} \mathrm{C}$ date discrepencies, Geological Survey of Canada, Paper 81-1B: 105-111.

FLORIN, M.-B., and WRIGHT, H. E., Jr. (1969): Diatom evidence for the persistence of stagnant glacial ice in Minnesota, The Geological Society of America, Bulletin, 80: 695-704.

FULTON, R. J., and HODGSON, D. A. (1979): Wisconsin glacial retreat, southern Labrador, Geological Survey of Canada, Paper 79-1C: $17-21$.

GEYH, M. A., KRUMBEIN, W. E., and KUDRAUS, H. R. (1974): Unreliable ${ }^{14} \mathrm{C}$ dating of long-stored deep-sea sediments due to bacterial activity, Marine Geology, 17: 45-50.

GRANT, D. R. (1969a): Surficial deposits, geomorphic features, and Late Quaternary history of the terminus of the Northern Peninsula of Newfoundland and adjacent Quebec-Labrador, Maritime Sediments, 5: 123-125.

(1969b): Late Pleistocene re-advance of Piedmont glaciers in Western Newfoundland, Maritime Sediments, 5: 126-128. 
(1971): Geomorphology, Lake Melville area, Labrador (13 F and G), Geological Survey of Canada, Paper 71-1B: 114-117.

- (in press) : Surficial geology of St.-Anthony-Blanc Sablon map areas, northern Newfoundland and adjacent Quebec-Labrador, Geological Survey of Canada, Memoir.

GRAYSON, J. F. (1956): The postglacial history of vegetation and climate in the Labrador-Quebec region as determined by palynology, Ph.D. thesis, University of Michigan, Ann Arbor, Michigan, $252 p$.

GREENE, B. A. (1974): An outline of the geology of Labrador, Mineral Development Division, Dept. Mines and Energy, Province of Newfoundland, Information Circular No. 15, 64 p.

GROOTES, P. M. (1983): Radioactive isotopes in the Holocene, in WRIGHT, H. E., Jr. (edit.), Late-Quaternary Environments of the United States, Vol. 2, University of Minnesota Press, p. 86-105.

HARE, F. K. (1959): A photo-reconnaissance of Labrador-Ungava, Geographical Branch, Dept. of Mines and Tech. Resources, Memoir 6, Ottawa.

HILLAIRE-MARCEL, C., and OCCHIETTI, S. (1980): Chronology, paleogeography, and paleoclimatic significance of the late and post-glacial events in eastern Canada, Zeitschrift fur Geomorphologie, 24: 373-392.

HODGSON, D. A., and FULTON, R. J. (1972): Site description, age and significance of a shell sample from the mouth of the Michael river, $30 \mathrm{~km}$ south of Cape Harrison, Labrador, Geological Survey of Canada, Paper 72-1B: 102-105.

HUGHES, O. L. (1964): Surficial geology of Nichoun-Kaniapiskau Map area, Quebec, Geological Survey of Canada Bulletin 106 $20 \mathrm{p}$.

HYVÄRINEN, H. (1973): The deglaciation history of eastern Fennoscandia-recent data from Finland, Boreas, 2: 85-102.

IVES, J. D. (1960a): The deglaciation of Labrador-Ungava: an outline, Cahiers de géographie de Québec, $4: 323-343$.

(1960b): Glaciation and deglaciation of the Helluva Lake area, central Labrador-Ungava, Geographical Bulletin, 15: 46-63.

IVES, J. D., ANDREWS, J. T., and BARRY, R. G. (1975): Growth and decay of the Laurentice Ice Sheet and comparison with FennoScandia, Die Naturwissen Schaften, 62: 118-125.

JORDAN, R. (1975): Pollen diagrams from Hamilton Inlet, central Labrador, and their implications for the northern Maritime Archaic, Arctic Anthropology, 12: 92-116.

JOSENHANS, H. W. (1983): Evidence of pre-late Wisconsin glaciations on Labrador Shelf-Cartwright Saddle region, Canadian Journal of Earth Sciences, 20: 225-235.

KING, G. A. (1986) : Deglaciation and Vegetation History of Western Labrador and Adjacent Quebec, Ph.D. thesis. in prep. University of Minnesota, Minneapolis, Minnesota.

KING, J. W., LONG, A., BANERJEE, S. K., WRIGHT, H. E., Jr., and $\mathrm{HOLSCHUH}, \mathrm{N}$. (1983) Evaluation of ${ }^{14} \mathrm{C}$ ages from lake sediments by a combination of sedimentologic, palynologic and paleomagnetic studies, in KING, J., Geomagnetic Secular Variation Curves for Northeastern North America for the Last 9,000 Years B.P., Ph.D. thesis, University of Minnesota, Minneapolis, Minnesota.

LAMB, H. F. (1978): Post-glacial Vegetation Change in Southeastern Labrador, M. S. thesis, University of Minnesota, Minneapolis, Minnesota, $101 \mathrm{p}$.

(1980): Late Quaternary vegetational history of southeastern Labrador, Arctic and Alpine Research, 12(2): 117-135.
(1985): Palynological evidence for postglacial change in the position of tree limit in Labrador, Ecological Monographs, 55: 241-258.

LOWDON, J. A., and BLAKE, W., Jr. (1973): Geological Survey of Canada radiocarbon dates XIII, Geological Survey of Canada, Paper 73-7, $61 \mathrm{p}$.

(1975): Geological Survey of Canada radiocarbon dates XV, Geological Survey of Canada, Paper 75-7, 32 p.

(1979) : Geological Survey of Canada radiocarbon dates XIX, Geological Survey of Canada, Paper 79-7, 58 p.

(1980): Geological Survey of Canada radiocarbon dates XX, Geological Survey of Canada, Paper 80-7, 28 p.

MANGERUD, J. (1972): Radiocarbon dating of marine shells, including a discussion of apparent age of recent shells from Norway, Boreas, 1: 143-172.

MANGERUD, J., and GULLIKSEN, S. (1975): Apparent radiocarbon ages of recent marine shells from Norway, Spitsbergen, and Arctic Canada, Quaternary Research, 5: 263-275.

MAYEWSKI, P., DENTON, G. H., and HUGHES, T. J. (1981): Late Wisconsin ice sheets in North America, in DENTON, G. H., and HUGHES, T. J. (edit.), The Last Great Ice Sheets, J. Wiley and Sons, New York, p. 67-178.

MORRISON, A. (1970): Pollen diagrams from interior Labrador, Canadian Journal of Botany, 98: 1957-1975.

MOTT, R. J. (1976): A Holocene pollen profile from the Sept-îles area, Québec, Naturaliste canadien, 103: 457-476.

PAINCHAUD, A., DUBOIS, J. M. M., and GYWN, Q. H. J. (1984): Déglaciation et émersion des terres de l'ouest de l'île d'Anticosti, Golfe du Saint-Laurent, Québec, Géographie physique et Quaternaire, 38(2): 93-111.

PREST, V. K. (1969): Retreat of Wisconsin and recent ice in North America, Geological Survey of Canada, Map 1257A, scale 1/ $5,000,000$.

(1984): The Late Wisconsin glacier complex, in FULTON, R. J. (edit.), Quaternary Stratigraphy of Canada-A Canadian Contribution to IGCP Project 24, Geological Survey of Canada, Paper 84-10: 21-36.

RICHARD, P. J. H., LAROUCHE, A., and BOUCHARD, M. A. (1982): Âge de la déglaciation finale et histoire post glaciaire de la végétation dans la partie centrale du nouveau-Québec, Géographie physique et Quaternaire, 36: 63-90.

ROGERSON, R. J. (1977): Glacial geomorphology and sediments of the Porcupine Strand area, Labrador, Canada, Ph.D. thesis, Macquarie University, New South Wales, 275 p.

(1981): The tectonic evolution and surface morphology of Newfoundland, in MACPHERSON, A. G., and MACPHERSON, J. B. (edit.), The Natural Environment of Newfoundland, Past and Present, Memorial University Printing Services, $265 \mathrm{p}$.

RUDDIMAN, W. F., and McINTRYE, A. (1981): The North Atlantic ocean during the last deglaciation, Palaeogeography, Paleoclimatology, Palaeoecology, 35: 145-214.

SAUVÉ, P., et LASALLE, P. (1969): Notes sur la géologie glaciaire de la région de Manic 2, Naturaliste canadien, 95: 1293-1300.

SHORT, S. K., edit. (1981): Radiocarbon date list 1. Labrador and Northern Quebec, Canada, Institute for Arctic and Alpine Research Occasional Paper no. 36, $33 \mathrm{p}$. 
SHORT, S. K., and NICHOLS, H. (1977): Holocene pollen diagrams from subarctic Labrador-Ungava: vegetational history and climatic change, Arctic and Alpine Research, 9: 265-290.

STRAVERS, L. K. S. (1981): Palynology and deglaciation history of the Central Labrador-Ungava Peninsula, M.S. thesis, University of Colorado, Boulder, Colorado, $171 \mathrm{p}$.

SUESS, H. E. (1970): Bristlecone-pine calibration of the radiocarbon timescale 5200 B.C. to the present, in OLSON, I. V. (edit.), Proceedings of the Twelfth Nobel Symposium on Radiocarbon Variations and Absolute Chronology, Uppsala, Almqvist and Wiksell, Forlag AB, Stockholm, p. 303-311.

SUTHERLAND, D. G. (1980): Problems of radiocarbon dating deposits from newly deglaciated terrain: examples from the Scottich La- teglacial, in LOWE, J. J., GRAY, J. M. and ROBINSON, J. E. (edit.), Studies in the Lateglacial of North-West Europe, Pergamon Press, Oxford, p. 139-149.

VILKS, G., and MUDIE, P. J. (1978): Early deglaciation of the Labrador Shelf, Science, 202: 1181-1183.

(1983): Evidence for postglacial paleoceanographic and paleoclimatic changes in Lake Melville, Labrador, Canada, Arctic and Alpine Research, 15: 307-320.

VILKS, G., HARDY, I., and JOSENHANS, H. W. (1984) : Late Quarternary stratigraphy of the inner Labrador shelf, Geological Survey of Canada, Paper 84-1A: 57-65.

WRIGHT, H. E., Jr., MANN, D. H., and GLASER, P. H. (1984): Piston corers for peat and lake sediments, Ecology, 65: 657-659.

\section{APPENDIX}

\section{LOCATION, REFERENCE, AND EVALUATION OF RADIOCARBON DATES INDICATING DEGLACIATION TIME FOR THE SOUTHEASTERN PART OF THE LABRADOR-UNGAVA PENINSULA}

Organization of data entries:

First line: Site number, Site name, Elevation, Lab number, Reported age, \% organic matter content of sample (\&), Sample thickness (\&), Sample height above glacial sediments (\&), Evaluation, Correction (\&), Method for determining correction (see Table II) (\&), Corrected date, $\mathrm{X}$ if date used in the reconstruction

Second line: Site location, Reference, Dated material, Comments.

Note: 1. Entries followed by a (\&) do not apply to dates of marine shells

2. Reported errors for non-GSC dates are one standard deviation, and two standard deviations for GSC dates.

1. Whitney's Gulch $99 \mathrm{~m} \quad \mathrm{SI}-3137 \quad 9820 \pm 110 \quad 20 \% \quad 10 \mathrm{~cm} \quad$ Y1b 635 A2,B2 $\quad 10.5 \times$ $51^{\circ} 31^{\prime} \mathrm{N} \quad 57^{\circ} 18^{\prime} \mathrm{W}$, Lamb, 1980 . Greenish gyttja.

2. Lac Salé de l'Est 2 m GSC-3325 $8930 \pm 80 \quad$ Shell date. G $8.9 \times$

$51^{\circ} 27^{\prime} \mathrm{N}, 57^{\circ} 42^{\prime} \mathrm{W}$, Blake, 1983. Shells deposited between inner two of three moraines on coast. Outer moraine is the Belles Amours Moraine (Grant, in press).

3. Pinware River mouth $9 \mathrm{~m} \quad$ GSC-2825 $10900 \pm 140 \quad$ Shell date. G $10.9 \times$ $51^{\circ} 32^{\prime} \mathrm{N} \quad 56^{\circ} 44^{\prime} \mathrm{W}$, Lowdon and Blake, 1979. Minimum time for deglaciation and incursion of sea up the Pinware River valley.

4. Moraine Lake $385 \mathrm{~m} \quad$ GSC-3067 $9640 \pm 170 \quad 4 \% \quad 5 \mathrm{~cm} \quad 50 \mathrm{~cm} \quad$ G $\quad$ B2 $\quad 9.7 \times$ $52^{\circ} 16^{\prime} \mathrm{N} \quad 58^{\circ} 03^{\prime} \mathrm{W}$, Engstrom and Hansen, 1985. Silt. Lake is situated on the Paradise Moraine and is an ice-block depression. Deglaciation time may be earlier.

5. Lake Hope Simpson $295 \mathrm{~m} \quad$ GSC-3022 $10400 \pm 140 \quad 3 \% \quad 11 \mathrm{~cm} \quad 6 \mathrm{~cm} \quad$ G* 100 B2 $10.5 \times$ $52^{\circ} 27^{\prime} \mathrm{N} \quad 56^{\circ} 20^{\prime} \mathrm{W}$. Engstrom and Hansen, 1985. Silty gyttja.

6. Paradise Lake $180 \mathrm{~m} \quad \mathrm{SI}-3348 \quad 9810 \pm 120 \quad 2 \% \quad 20 \mathrm{~cm} 30 \mathrm{~cm} \quad$ GC* $\quad 102 \quad$ A2,B2 $\quad 10.8 \times$ $53^{\circ} 03^{\prime} \mathrm{N} 57^{\circ} 45^{\prime} \mathrm{W}$, Lamb, 1980. Silty gyttja dated. Glacial varves may be present.

$\begin{array}{lllllllll}\text { 7. Eagle Lake } 400 \mathrm{~m} & \mathrm{SI}-3139 & 10550 \pm 290 & 2 \% & 20 \mathrm{~cm} 10 \mathrm{~cm} & \mathrm{G}^{*} & 100 & \mathrm{~B} 2 & 10.7 \times\end{array}$ $53^{\circ} 14^{\prime} \mathrm{N} \quad 58^{\circ} 33^{\prime} \mathrm{W}$, Lamb, 1980. Silt dated.

8. Pinware Lake $240 \mathrm{~m} \quad$ GSC-3604 $\quad 7500 \pm 110 \quad 9 \% \quad 6 \mathrm{~cm} \mathrm{10} \mathrm{cm} \quad$ N6 $\quad 100 \quad$ B2 $\quad 7.6$ $51^{\circ} 50^{\prime} \mathrm{N} \quad 56^{\circ} 35^{\prime} \mathrm{W}$, King, 1986. Gyttja.

9. Alexis Lake $200 \mathrm{~m} \quad 52^{\circ} 31^{\prime} \mathrm{N} \quad 57^{\circ} 02^{\prime} \mathrm{W} \quad$ Grey silt dated. N3 Lamb, 1978. The following dates are in stratigraphic order, starting in the upper left. Percentages listed are \% organic matter (dry weight).

$\begin{array}{rrlrrr}\text { SI-4404 } & 7715 \pm 165 & 9 \% & \text { SI-4408 } & 2700 \pm 650 & 3 \% \\ \text { SI-4405 } & 13110 \pm 330 & 3 \% & \text { SI-3351 } & 14450 \pm 185 & 3 \% \\ \text { SI-3350 } & 9885 \pm 145 & 3 \% & \text { SI-4409 } & 28900 \pm 700 & 3 \% \\ \text { SI-4406 } & 15050 \pm 330 & 3 \% & \text { SI-4025 } & 12130 \pm 120 & 3 \% \\ \text { SI-4407 } & 13410 \pm 365 & 3 \% & \text { SI-3352 } & 20520 \pm 400 & 3 \% \\ \text { SI-4024 } & 8610 \pm 120 & 3 \% & \text { SI-4410 } & 13640 \pm 120 & 3 \%\end{array}$

10. Dove Brook, Sandwich Bay $2 \mathrm{~m} \quad$ GSC-2196 $7980 \pm 100 \quad$ Shell date N6 8.0 $53^{\circ} 38^{\prime} \mathrm{N}, 57^{\circ} 26^{\prime} \mathrm{W}$, Rogerson, 1977, Blake, 1983. Marine shells from oldest postglacial deposit in area. Blake (1983) suggests date is younger than local deglaciation time.

11. Rivière à l'Huile $12 \mathrm{~m} \quad$ UQ-719 $9010 \pm 60$ Shell date G $9.0 \times$ $49^{\circ} 12^{\prime} \mathrm{N}, 62^{\circ} 47^{\prime} \mathrm{W}$, Painchaud et al., 1984. Shells in glacial diamicton. Dates Rivière à l'Huile moraine on Anticosti Island.

12. Baie Martin $10 \mathrm{~m} \quad$ UQ-176 $9450 \pm 200 \quad$ Shell date G $9.5 \times$ 
$49^{\circ} 52^{\prime} \mathrm{N}, 63^{\circ} 52^{\prime} \mathrm{W}$, Painchaud et al., 1984. Shells deposited in silty sand in the Rivière à l'Huile Moraine. Sea level was $60-65 \mathrm{~m}$ when shells were deposited.

13. Rivière-à-la-Chaloupe $3 \mathrm{~m} \quad$ GIF-3770 $\quad 10230 \pm 180 \quad$ Shell date $\mathrm{G} \quad 10.2 \times$

$50^{\circ} 17^{\prime} \mathrm{N} \quad 65^{\circ} 07^{\prime} \mathrm{W}$, Dubois, 1977. Shells deposited in estuarine environment.

14. Sept-îles area $76 \mathrm{~m} \quad$ GSC-1337 $9140 \pm 200 \quad$ Shell date G $9.1 \times$

$50^{\circ} 18^{\prime} \mathrm{N} \quad 66^{\circ} 12^{\prime} \mathrm{W}$, Dredge, 1976a. Dates maximum marine level in area.

15. Pointe-Noire $125 \mathrm{~m} \quad$ QU-209 $9350 \pm 260 \quad$ Shell date G $9.4 \times$

$50^{\circ} 18^{\prime} \mathrm{N} \quad 66^{\circ} 27^{\prime} \mathrm{W}$, Dubois, 1977. Shells in littoral sand and gravel and date the Lac Daigle moraine.

16. Lac Pétel $290 \mathrm{~m} \quad$ GSC-3716 $7710 \pm 90 \quad 5 \% \quad 5 \mathrm{~cm} 6 \mathrm{~cm} \quad$ G $\quad 350$ A2,B1 $8.1 \times$

$50^{\circ} 33^{\prime} \mathrm{N} \quad 66^{\circ} 16^{\prime} \mathrm{W}, \mathrm{King}, 1986$. Silty gyttja above glacial varves. 100 varves counted.

17. Baie-Comeau $60 \mathrm{~m}$ GSC-1565 $9280 \pm 140$ Shell date G $9.3 \times$ $49^{\circ} 13 \mathrm{~N} \quad 68^{\circ} 12 \mathrm{~W}$, Dubois, 1977. Shells deposited in marine clay.

18. Manic $2 \quad 64 \mathrm{~m} \quad \mathrm{I}-3868 \quad 9150 \pm 150 \quad$ Shell date $\quad \mathrm{G} \quad 9.2 \mathrm{X}$

$49^{\circ} 19^{\prime} \mathrm{N}, 68^{\circ} 21^{\prime} \mathrm{W}$, Sauvé and LaSalle, 1968. Shells deposited in marine clay under glacial-fluvial deposits. Dates the Québec North Shore Moraine system.

19. LD Lake $122 \mathrm{~m} \quad$ GSC-1811 $6960 \pm 300 \quad--10 \mathrm{~cm} \quad--\quad \mathrm{Y} 1 \mathrm{~b} \quad$-$50^{\circ} 08^{\prime} \mathrm{N} \quad 67^{\circ} 08^{\prime} \mathrm{W}$, Mott, 1976. Organic sand and silt above banded clay.

20. Michael River mouth GSC-1453 $8640 \pm 230 \quad$ Shell date G $10.0 \times$ $54^{\circ} 41^{\prime} \mathrm{N} \quad 57^{\circ} 49^{\prime} \mathrm{W}$, Hodgson and Fulton, 1972. Dated shells were deposited in offshore silt, $20 \mathrm{~m}$ below maximum marine limit. Using regional emergence curves the authors estimate the local deglaciation time to be $10.0 \mathrm{~K}$.

21. Saint John Island Pond $137 \mathrm{~m} \quad \mathrm{SI}-1737 \quad 10240 \pm 1240 \quad--\quad 26 \mathrm{~cm} \quad--\quad$ GR100 $\quad$ B2 $10.3 \times$ $53^{\circ} 57^{\prime} \mathrm{N} \quad 58^{\circ} 55^{\prime} \mathrm{W}$, Jordan, 1975 . Gyttja clay transition, above sandy clay.

22. Lake Melville GSC-3185 $7530- \pm 120 \quad--\quad 20 \mathrm{~cm} \quad 494 \mathrm{~cm} \quad$ C1700 A2 $\quad 9.2 \times$ $53^{\circ} 50^{\prime} \mathrm{N}, 59^{\circ} 12^{\prime} \mathrm{W}$, Vilks and Mudie, 1984. Sample from core 111, Lake Melville.

23. Northwest River $27 \mathrm{~m} \quad$ GSC-2970 $7600 \pm 100 \quad$ Shell date G $7.6 \times$

$53^{\circ} 32^{\prime} \mathrm{N} \quad 60^{\circ} 09^{\prime} \mathrm{W}$, Lowdon and Blake, 1980. Barnacle shells in compact marine mud collected from top of end moraine (Blake, 1956).

24. Muskrat Falls area GSC-1254 $7490 \pm 150$ Shell date G $7.5 \times$ $53^{\circ} 15^{\prime} \mathrm{N}, 60^{\circ} 45^{\prime} \mathrm{W}$, Lowdon and Blake, 1975. Minimum deglaciation date; postdates end moraines at Northwest River (Blake, 1956) and southeast of Goose Bay (Grant, 1971).

25. The Backway $1.5 \mathrm{~m} \quad$ GSC-2465 $6890 \pm 190 \quad$ Shell date N6 6.9 $54^{\circ} 05^{\prime} \mathrm{N}, 58^{\circ} 47^{\prime} \mathrm{W}$, Rogerson, 1977, Blake, 1983. Shells from earliest postglacial sediment in area. Blake (1983) suggests date younger than local deglaciation time.

26. Alexander Lake $143 \mathrm{~m} \quad \mathrm{SI}-1331 \quad 5985 \pm 140 \quad--\quad 20 \mathrm{~cm} 20 \mathrm{~cm} \quad \mathrm{Y} 1 \mathrm{~b} \quad$-- $\quad$-$53^{\circ} 20^{\prime} \mathrm{N}, 60^{\circ} 35^{\prime} \mathrm{W}$, Jordan, 1975 . Gyttja above clayey gyttja.

27. Aluik Pond $25 \mathrm{~cm} \quad \mathrm{SI}-1531 \quad 7170 \pm 180 \quad--22 \mathrm{~cm} 11 \mathrm{~cm} \quad \mathrm{Y} 1 \mathrm{~b} \quad$-_ $\quad$-$54^{\circ} 35^{\prime} \mathrm{N} \quad 57^{\circ} 22^{\prime} \mathrm{W}$, Jordan, 1975. Gyttja-clay transition above grey clay.

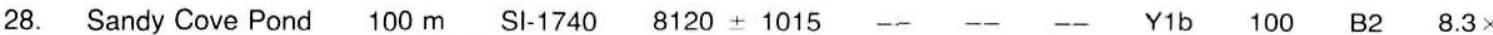
$54^{\circ} 24^{\prime} \mathrm{N}, 57^{\circ} 43^{\prime} \mathrm{W} \quad$ SI-1739 $8155 \pm 405 \quad \ldots \quad \ldots \quad \ldots \quad$ Jordan, 1975. Both dates from the gyttja-clay transition just above clay.

29. Northwest River Pond $29 \mathrm{~m} \quad \mathrm{SI}-1332 \quad 4804 \pm 55 \quad-\quad 20 \mathrm{~cm} 12 \mathrm{~cm} \quad \mathrm{Y} 1 \mathrm{~b} \quad$-- $\quad$-$53^{\circ} 31^{\prime} \mathrm{N}, 60^{\circ} 10^{\prime} \mathrm{W}, \quad J o r d a n, 1975$. Gyttja, $40 \%$ Picea pollen in dated sample. Pond is on a sandy recessional moraine.

30. Battery Lake $430 \mathrm{~m} \quad$ GSC-3661 $6980 \pm 110 \quad 6 \% \quad 5 \mathrm{~cm} 15 \mathrm{~cm} \quad$ G $\quad \begin{array}{lllll}700 & \text { A2,B2 } & 7.7 \times\end{array}$ $52^{\circ} 18^{\prime} \mathrm{N}, 62^{\circ} 07^{\prime} \mathrm{W}$, King, $1986 . \quad$ Silty gyttja.

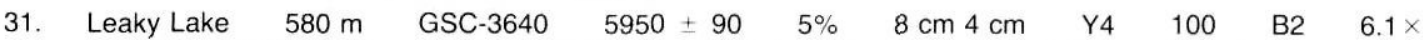
$52^{\circ} 34^{\prime} \mathrm{N}, 63^{\circ} 36^{\prime} \mathrm{W}$, King, 1986. Silty-gyttja. $1 \mathrm{~m}$ of glacial silt overlies at least $10 \mathrm{~cm}$ of sand.

32. Lac au Sable $530 \mathrm{~m} \quad$ GSC-3720 $6860 \pm 100 \quad 5 \% \quad 5 \mathrm{~cm} 8 \mathrm{~cm} \quad$ G $\quad 381 \quad$ A $1, \mathrm{~B} 2 \quad 7.2 \times$ $51^{\circ} 24^{\prime}, 66^{\circ} 13^{\prime} \mathrm{W}$, King, $1986 . \quad$ Silty-gyttja.

33. Shovel Fen $550 \mathrm{~m} \quad$ WIS-1527 $5940 \pm 80 \quad--\quad 3 \mathrm{~cm} 4 \mathrm{~cm} \quad$ Y2 $\quad \begin{array}{lllll}100 & \text { B2 } & 6.0 \times\end{array}$ $52^{\circ} 32^{\prime} \mathrm{N}, 65^{\circ} 56^{\prime} \mathrm{W}$, King, 1986. Basal peat date.

34. Lac Gras $560 \mathrm{~m} \quad$ GSC-3615 $\quad 6510 \pm 110 \quad 8 \% \quad 12 \mathrm{~cm} 8 \mathrm{~cm} \quad$ G $\quad 145 \quad$ A $1, \mathrm{~B} 2 \quad 6.7 \times$ $52^{\circ} 15^{\prime} \mathrm{N}, 67^{\prime} 04^{\prime} \mathrm{W}$, King, $1986 . \quad$ Silty-gytța.

35. Pine Lake $300-450 \mathrm{~m} \quad$ GSC-3595 $6450 \pm 90 \quad 7 \% \quad 4 \mathrm{~cm} 4 \mathrm{~cm} \quad$ G $\quad \begin{array}{lllll}100 & \text { B2 } & 6.6 \times\end{array}$ $51^{\circ} 08^{\prime} \mathrm{N}, 69^{\prime} 16^{\prime} \mathrm{W}$. King. 1986. Gyttja. Two samples combined for dating

36. Cove Lake $450-610 \mathrm{~m} \quad$ GSC-3569 $6010 \pm 90 \quad 15 \% \quad 10 \mathrm{~cm} \quad$ - $\quad$ Y2 $\quad 100 \quad$ B2 $6.1 \times$ $50^{\circ} 21^{\prime} \mathrm{N}, 70^{\circ} 28^{\prime} \mathrm{W}$, King, 1986. Silty-gyttja. Spruce percentages from dated sample are $30 \%$, indicating that earliest postglacial sediments not sampled. 
37. Starkel Lake $625 \mathrm{~m} \quad$ GSC-3644 $6200 \pm 100 \quad 7 \% \quad 5 \mathrm{~cm} 7 \mathrm{~cm} \quad$ G $\quad \begin{array}{lllll}100 & \text { B2 } & 6.3 \times\end{array}$ $52^{\circ} 41^{\prime} \mathrm{N}, 67^{\circ} 37^{\prime} \mathrm{W}$, King 1986. Gyttja. Basal sediments of three cores dated.

38. Harrie Lake $530 \mathrm{~m} \quad$ GSC-3616 $6030 \pm 110 \quad 5 \% \quad 20 \mathrm{~cm} \quad 10 \mathrm{~cm} \quad$ G $\quad \begin{array}{lllll}133 & \mathrm{~A} 1, \mathrm{~B} 2 & 6.2 \times\end{array}$ $52^{\circ} 56^{\prime} \mathrm{N}, 66^{\circ} 57^{\prime} \mathrm{W}$, King, 1986. Silty-gyttja.

39. Horseshoe Lake $690 \mathrm{~m} \quad$ GSC-3658 $5770 \pm 70 \quad 5 \% \quad 7 \mathrm{~cm} 31 \mathrm{~cm} \quad \mathrm{Y} 3 \quad$-- $\quad$-$53^{\circ} 17^{\prime} \mathrm{N}, 67^{\circ} 42^{\prime} \mathrm{W}$, King, 1986 . Silty-gyttja.

40. Coghill Lake $520 \mathrm{~m} \quad$ GSC-3625 $5400 \pm 90 \quad 4 \% \quad 7 \mathrm{~cm} 27 \mathrm{~cm} \quad$ GC $\quad 762 \quad$ A1,B2 $\quad 6.2 \times$ $53^{\circ} 36^{\prime} \mathrm{N}, 66^{\circ} 46^{\prime} \mathrm{W}$, King, 1986 . Silty gyttja dated.

41. Churchill Falls North $405 \mathrm{~m} \quad 1-880 \quad 5255 \pm 200 \quad \ldots \quad 6 \mathrm{~cm} 25 \mathrm{~cm} \quad$ Y2 $\quad 100 \quad$ B2 $\quad 5.4 \times$ $53^{\circ} 36^{\prime} \mathrm{N}, 64^{\circ} 19^{\prime} \mathrm{W}$, Morrison, 1970. Bog pool cored. Material dated is bulrush peat. Dates increase in spruce percentages.

42. Churchill Falls South $405 \mathrm{~m} \quad \mathrm{I}-853 \quad 5440 \pm 200 \quad--\quad 12 \mathrm{~cm} \quad-\quad$ Y2 $\quad 100 \quad$ B2 $5.4 \times$ $53^{\circ} 35^{\prime} \mathrm{N}, 64^{\circ} 18^{\prime} \mathrm{W}$, Morrison, 1970. Fen pool cored. Silty peat.

43. Sona Lake West $435 \mathrm{~m} \quad 1-728 \quad 5575 \pm 250 \quad--\quad 10 \mathrm{~cm} 12 \mathrm{~cm} \quad$ Y2 $\quad \begin{array}{lllll}100 & \text { B2 } & 5.7 \times\end{array}$ $53^{\circ} 35^{\prime} \mathrm{N}, 63^{\circ} 57^{\prime} \mathrm{W}$, Morrison, 1970 . Fen cored. Sandy peat.

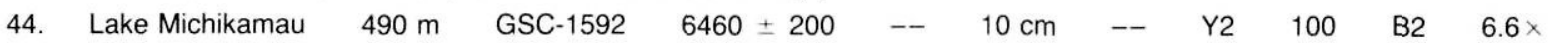
$54^{\circ} 00^{\prime} \mathrm{N}, 63^{\circ} 00^{\prime} \mathrm{W}$, Lowdon and Blake, 1973. Basal peat and mucky silt.

45. Gravel Ridge $559 \mathrm{~m} \quad$ GSC-3252 $\quad 6470 \pm 150 \quad 3 \% \quad 10 \mathrm{~cm} 5 \mathrm{~cm} \quad$ G* $^{*} \quad \begin{array}{lllll}100 & \text { B2 } & 6.6 \times\end{array}$ $55^{\circ} 02^{\prime} \mathrm{N}, 62^{\circ} 38^{\prime} \mathrm{W}$, Lamb, $1985 . \quad$ Silty gyttja.

46. Border Beacon $470 \mathrm{~m} \quad$ GSC-3241 $6500 \pm 100 \quad 3 \% \quad 10 \mathrm{~cm} 5 \mathrm{~cm} \quad$ G $^{*} \quad 100 \quad$ B2 $\quad 6.6 \times$ $55^{\circ} 20^{\prime} \mathrm{N}, 63^{\circ} 12^{\prime} \mathrm{W}$, Lamb, $1985 . \quad$ Grey brown silt.

47. Caribou Hill $475 \mathrm{~m} \quad$ GSC-3238 $\quad 6120 \pm 140 \quad 3 \% \quad 10 \mathrm{~cm} \quad 3 \mathrm{~cm} \quad$ G $^{*} \quad \begin{array}{llllll}100 & \text { B } 2 & 6.2 \times\end{array}$ $55^{\circ} 40^{\prime} \mathrm{N}, 63^{\circ} 15^{\prime} \mathrm{W}$, Lamb, 1985 . Silty-gyttja.

48. Hopedale Pond $76 \mathrm{~m} \quad \mathrm{SI}-1961 \quad 5440 \pm 150 \quad--\quad 1.5 \mathrm{~cm} 11 \mathrm{~cm} \quad$ N6 $\quad 100 \quad$ B2 5.5 $55^{\circ} 28^{\prime} \mathrm{N}, 60^{\circ} 17^{\prime} \mathrm{W}$, Short and Nichols, 1977, Short, 1981. Necron mud above gravel and clay.

49. Shovel Lake $550 \mathrm{~m} \quad$ GSC-3638 $\quad 3860 \pm 70 \quad 5 \% \quad 6 \mathrm{~cm} 8 \mathrm{~cm} \quad$ N6 $\quad 100 \quad$ B2 $\quad 4.0$ $52^{\circ} 42^{\prime} \mathrm{N}, 65^{\circ} 55^{\prime} \mathrm{W}$, King, $1986 . \quad$ Gyttja.

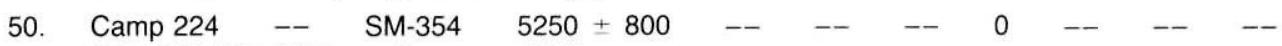
$52^{\circ} 59^{\prime} \mathrm{N}, 66^{\circ} 15^{\prime} \mathrm{W}, \quad$ Grayson, 1956.

51. Bruce Lake $580 \mathrm{~m} \quad$ GSC-3626 $4150 \pm 150 \quad 5 \% \quad 5 \mathrm{~cm} 16 \mathrm{~cm} \quad \mathrm{Y3} \quad$-- $\quad$-- $53^{\circ} 17^{\prime} \mathrm{N}, 66^{\circ} 50^{\prime}$, King, 1986. Silty-gyttja dated. Samples from two cores combined for dating.

52. Lac de la Crête $\quad 610-670 \mathrm{~m} \quad$ GSC-3551 $5200 \pm 110 \quad 5 \% \quad 5 \mathrm{~cm} \mathrm{6} \mathrm{cm} \quad$ N6 $\quad 100 \quad$ B2 $\quad 5.3$ $50^{\circ} 59^{\prime} \mathrm{N}, 69^{\circ} 53^{\prime} \mathrm{W}$, King, 1986 . Gyttja. Two samples combined for dating. Basal date is too young because of the site's high elevation.

53. Track Lake $440 \mathrm{~m} \quad \mathrm{SI}-1957 \quad 4755 \pm 85 \quad--\quad 4 \mathrm{~cm} 21 \mathrm{~cm} \quad$ N6 $\quad 366 \quad$ A2,B2 $\quad 5.3$ $55^{\circ} 46^{\prime} \mathrm{N}, 65^{\circ} 10^{\prime} \mathrm{W}$, Short and Nichols, 1977, Short, 1981. Necron mud.

54. Lac Ridge $500 \mathrm{~m} \quad$ GSC-3629 $8780 \pm 140 \quad 18 \% \quad 5 \mathrm{~cm} 4 \mathrm{~cm} \quad \mathrm{~N} 2 \quad--$ $54^{\circ} 51^{\prime} \mathrm{N}, 66^{\circ} 55^{\prime} \mathrm{W}$, King, 1986 . Gyttja.

55. Lac Hammard $564 \mathrm{~m} \quad$ GX-6354 $16975 \pm 1040 \quad 6 \% \quad 10 \mathrm{~cm} 5 \mathrm{~cm} \quad$ N3 $\quad$-- $\quad$-$54^{\circ} 48^{\prime} \mathrm{N}, 67^{\circ} 30^{\prime} \mathrm{W}$, Beta-1201 $6345 \pm 160 \quad 5 \% \quad 10 \mathrm{~cm} 33 \mathrm{~cm} \quad$ Stravers, 1981, Short, 1981, Silty-clay. Lake located on granitic bedrock.

56. Tunturi Lake $610 \mathrm{~m} \quad \mathrm{GX}-6366 \quad 14040 \pm 780 \quad 2 \% \quad 3 \mathrm{~cm} 4 \mathrm{~cm} \quad$ N3 $\quad--\quad$-- $\quad$-$55^{\circ} 01^{\prime}, 67^{\circ} 30^{\prime} \mathrm{W}$, Beta-1205 $5990 \pm 160 \quad 13 \% \quad 10 \mathrm{~cm} 55 \mathrm{~cm} \quad$ Stravers, 1981, Short, 1981. Basal clay and necron mud. Lake located on granitic bedrock.

57. Boundary lake $525 \mathrm{~m} \quad \mathrm{GX}-6975 \quad 6685 \pm 205 \quad 15 \% \quad 29 \mathrm{~cm} \quad--\quad \mathrm{N} 2 \quad--\quad--\quad 6.7$ $55^{\circ} 15^{\prime} \mathrm{N}, 67^{\circ} 24^{\prime} \mathrm{W}$, Stravers, 1981. Date slightly too old when compared to other nearby dates. Other dates from this lake:

$\begin{array}{clrl}252.5-262.5 \mathrm{~cm} & \text { GX-5520 .76\% O.M. } & 10700 & \pm 540 \\ 250-270 \mathrm{~cm} & \text { QL-1214 } & 9980 & \pm 40 \\ 270-280 \mathrm{~cm} & \text { QL-1214B } & 16330 & \pm 330\end{array}$

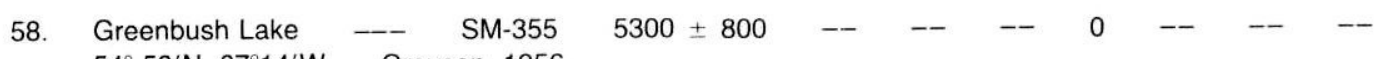
$54^{\circ} 59^{\prime} \mathrm{N}, 67^{\circ} 14^{\prime} \mathrm{W} \quad$ Grayson, 1956.

59. Daumont Lake $600 \mathrm{~m} \quad$ GSC-3052 $5490 \pm 80 \quad 10 \% \quad 5 \mathrm{~cm} 3 \mathrm{~cm} \quad$ G $\quad 103 \quad$ A1,B2 $\quad 5.6 \times$ $54^{\circ} 52^{\prime} \mathrm{N} \quad 69^{\circ} 24^{\prime} \mathrm{W}$, Richard et al., 1982. Gyttja above $25 \mathrm{~cm}$ of varved silts/clay and $30 \mathrm{~cm}$ of sand.

60. Delorme I $513 \mathrm{~m} \quad$ GSC-3139 $5330 \pm 120 \quad--5 \mathrm{~cm} 3 \mathrm{~cm} \quad$ G $\quad 100 \quad$ B2 $\quad 5.4 \times$ $54^{\circ} 25^{\prime} \mathrm{N}, 69^{\circ} 55^{\prime} \mathrm{W}$, Richard et al., 1982 . Silty-gyttja above sand.

61. Delorme II $538 \mathrm{~m} \quad$ GSC-3094 $6320 \pm 180 \quad 7 \% \quad 5 \mathrm{~cm} 3 \mathrm{~cm} \quad$ G $\quad \begin{array}{llllll}100 & \text { B2 } & 6.4 \times\end{array}$ $54^{\circ} 25^{\prime} \mathrm{N}, 69^{\circ} 56^{\prime} \mathrm{W}$, Richard et al., 1982 . Silty-clay gyttja above sand.

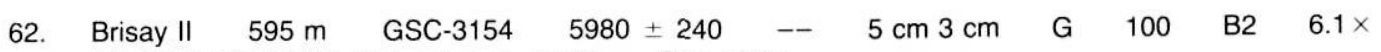
$54^{\circ} 21^{\prime} \mathrm{N}, 70^{\circ} 22^{\prime} \mathrm{W}$, Richard et al., 1982 . Silty gyttja. 